\title{
Geology of Wrangel Island in relation to the Chukchi Sea, OCS 109 sale area, 1986
}

Vaitl, J.D., and Amoco Oil Co.

GMC DATA REPORT 452

This GMC data report from the Amoco Heritage collection has been made available through funding from the FY2018 USGS National Geological and Geophysical Data Preservation Program, Grant Number G18AP00054. This project report is presented in its original format and has not been reviewed for technical content or for conformity to the editorial standards of DGGS. It should not be used or cited as reviewed data.

2019

State of Alaska

Department of Natural Resources

Division of Geological \& Geophysical Surveys

GEOLOGIC MATERIALS CENTER
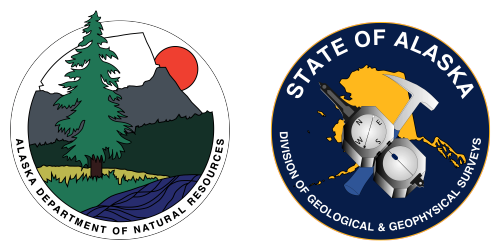


\section{AMOCO PRODUCTION COMPANY DENVER REGION NORTHERN DIVISION}

AREA Urangel Island - Chukchi Sea STATE Alaska/ H.S.S.R. COUNTY

\section{SUBJECT Geology of Wrangel Island in Relation to the Churkchi Sea oCS log Sale Area

Geologic Report NO NO-13-86R

DATE September 1986

BY J.D. Vait]

I- Topographic map , Wrangel Island

ㄹ.- Generalized Geologic Map I Pre-Cretaceous Rocks Chukotskiy Penins

$\exists$ Upper Triassic Measured Section 7 Southeast Shore, Wrangel Islan

4 - Upper Permian Measured Section , Neiyvestnya River 7 Wrangel Isla

5 Namurian $\{$ Late Mississippina $\}$ Measured Section 7 Cape Piiler 1

b - Visian-Namurian $\{$ Late Mississippian $\}$ Measured Section Cape Li

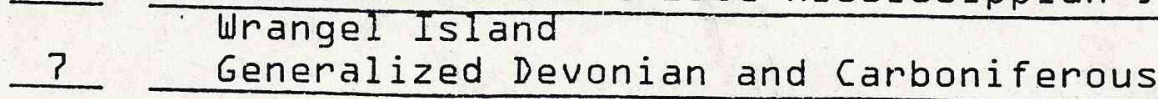

B Composite Stratigaphic Section T Chukotka Anyuy Area 


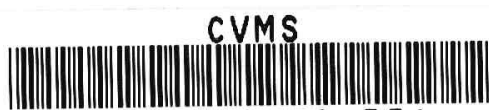

92-00664178-001

January 19,1987

TO: W.P. HARNACK

CHICAGO M/C 4701

RE: DENVER REGION GEOLOGIC MEMO \#NO-13-86R

GEOLOGY OF WRANGEL ISLAND IN RELATION TO CHUKCHI SEA OCS SALE \#109 AND WESTERN ALASKA

Transmitted herewith is the above mentioned Northe:n Division, Denver Region Geologic Memo by Jon Vaitl. This memo is based on a review ri available literature, translations of Russian publications, and conversations with visitors to Wrangel Island. Significant conclusions are that Wrangel is a thrusted package of rocks considerably displaced from its original position to the south. Triassic Ivishak equivalent sandstones are absent on Wrangel Island.

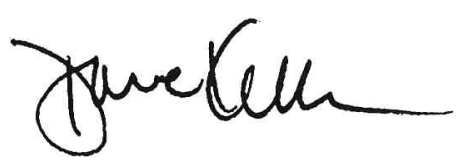

D.A. Keck

Northern Division Geological Manager

$\mathrm{DAK} / \mathrm{DTB} / \mathrm{kal}$ 
September 22,1986

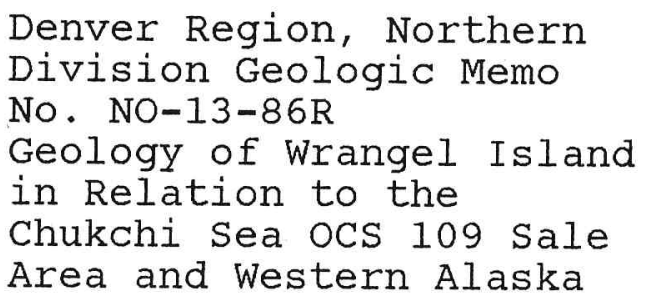

INTRODUCTION

CONCLUSIONS

RECOMIMENDATIONS

REFERENCES

ENCLOSURES

DISCUSSION

APPENDICIES

Translations of Russian Language Articles

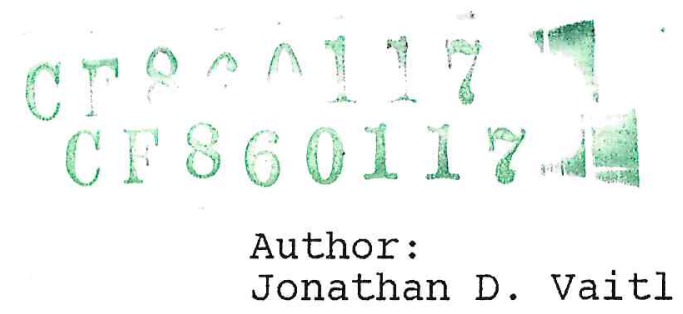


This report is based on a review of available English and translated Russian language literature on the geology of Wrangel Island and the Chukotka Peninsula. Information was also obtained by talking with individuals familiar with the area. The purpose of this study is to summarize the available structural and stratigraphic information as it pertains to the upcoming O.C.S. Sale 109. in the Chukchi sea.

\section{CONCLUSIONS}

1. Rocks exposed on Wrangel Island range in age from late pre-Cambrian to late Triassic with a thin Quaternary cover along the north and south coastal plains.

2. The entire section has been regionally metamorphosed to greenschist facies in post Triassic time and exhibits a penetrative deformational fabric.

3. The section on Wrangel Island has been thrust northward an unknown distance and is allochthinous relative to the equivalent section in the chukchi basin. The age of thrusting can only be constrained as being post Triassic.

4. The Upper Devonian thru Permian section on Wrangel Island is stratigraphically and lithologically similar to the section exposed on Cape Lisburne and the western Brooks Range. Similar section can be expected along the Herald Arch on the southern border of the O.C.S. No. 109 sale area.

5. There is a major angular unconformity between the Permian and the Upper Triassic on Wrangel Island and the Chukotka Peninsula which is not present in Alaska. The Upper Triassic (Norian) section on Wrangel Island consists of a thick sequence of turbidite deposits whereas in Alaska the equivalent section consists of thin, starved shelf deposits (Shublik formation).

6. No equivalent to the lower Triassic Ivishak formation is known to occur on Wrangel Island. This is contrary to the correlation reported by Churkin (1973), Meyerhoff (1973) and the Dobex report (1980) (WE-08-85R).

\section{RECOMMENDATIONS}

1. The stratigraphic information contained herein should be incorporated into Amoco's regional evaluation of the hydrocarbon potential of the Chukchi sea.

2. Attempts should be made to determine the amount of northward thrust displacement of the Wrangel Island terrain. Seismic mapping of the Herold arch, which is the subsea expression of the thrust fault trend connecting the Lisburne Peninsula to Wrangel Island, could help in determining an appropriate planinspastic reconstruction. 


\section{REFERENCES}

Chernyak, G. Ye. and Kameneva, G. I., 1976, Carboniferous and Permian Sediments of Wrangel Island; Geology, Doklady Akad. Nauk SSR, v. 227.

$\checkmark$ Dagis, A. S., et al., 1979, stratigraphy of the Triassic System of Northeastern Region of Asia, Izdalelstro Nauka, (In Russian) translated by Rapido Translations, 1986.

Dobex, 1985, The petroleum potential of the Arctic: Denver Region Amoco Vault Report, WE-08-85R.

Fujita, K. and Cook D. B., (in press), The Arctic Continental Margin of Eastern Siberia; in The Decade of North American Geology, vol. L, chapter 18.

Gnibidenko, G. S., 1968, More information on the paleozoic stratigraphy of Wrangel Island; Doklady Akud. Nauk. SSSR, Vol. 179.

Ivanov, O. N., 1979, Stratigraphy of Wrangel Islands; News from the Soviet Academy of Sciences - Geological Series (5): 104-115 (in Russian); translated by Infoplosion, Inc. 1986.

$\checkmark$ Kameneva, G. I., 1975, The geologic structures of the central part of Wrangel Island (in Russian) (rough translation obtained from Chris Harrison).

Kameneva, G. I., 1977, Tectonic setting of the Wrangel Island and its structural relationship with Alaska in the Paleozoic (in Russian) (translation obtained from Chris Harrison).

Tailleur, I. L., 1971, Translation of 1964 Correlations between Wrangel Island and Northern Alaska; USGS open file report $71-276$.

\section{ENCLOSURES}

1. Topographic Map, Wrangel Island

2. Generalized Geologic Map, Pre-Cretaceous

Rocks Chukotskiy Peninsula, USSR $1: 1,500,000$

3. Upper Triassic Measured Section, Southeast Shore, Wrangel Island

4. Upper Permian Measured Section, Neiyvestnaya River, Wrangel Island

5. Namurian (Late Mississippina) Measured Section, Cape Pillar, Wrangel Island

6. Visian-Namurian (Late Mississippian) Measured Section, Cape Litke, Wrangel Island

7. Generalized Devonian and Carboniferous

8. Composite Stratigraphic section, Chukotka -Anyuy Arrea

\section{DISCUSSION}

The following summary is based on the articles by Ivonof, $O$. N. (1973), Kameneva, G. I., et al. (1985, 1977), Dagys, A. S. (1968) which were translated from Russian as well as articles written in English by Tailleur, I. L., (1971) and Fujita, K., 
and Cook, D. B., (in press). In addition, information was obtained by personal communication with Chris Harrison of the Canadian Geologic Survey, who spent several weeks with a geologic expedition to Wrangel Island during the summer of 1986.

\section{Pre-Cambrian and Cambrian}

The oldest exposed formations on this island are metamorphosed sedimentary and volcanic rocks which occur in the central mountain range at the base of the laterally extensive thrust sheet. The oldest unit is the Gromov formation which has a thickness of at least 2,000 meters. It is composed of actinolite-epidote-chlorite schists with rare lenses of garnetepidote-diopside marbles. The protolith is recognizable as coarse grained arkosic sandstones and tuffs with interbedded siltstone, shale and minor carbonate.

Overlying the Gromov formation is the Inkalin formation. The protolith of the Inkalin formation is largely non-marine and consists of polymitic conglomerates, arkose and subarkosic sandstones and tuffs. The estimated thickness of this unit is 810 meters. It contains a metamorphic mineral assemblage of actinolite-epidote-chlorite and quartz-albite-muscovitechloritic typical of greenschist grade metamorphism. The age of this unit is reported to be vendian which is the youngest stage in the Pre-Cambrian in Russian stratigraphy. However, this age assignment is based on lithologic correlation with the section on the siberian Platform which is probably an incorrect assumption.

Stratigraphically above the Inkalin formation is the Naskhok formation. This consists of a basal polymictic and quartzitic conglomerate overlain by quartzite sandstone and minor phyllite. There is presumed to be an unconformity at the base of this unit which has an estimated thickness of 800 meters. The age of this section is reported to be early Cambrian based on poorly preserved acritarch and lower Cambrian algaes.

\section{Silurian and Lower Devonian}

The Drem-Khed formation is named for its outcrop occurrence in the Drem-Khed Mountain area in the extreme northwest part of the island. This unit consists of 400 meters of dark grey and black phyllitic slates, siltstone and quartzitic fine grained sandstone with abundant occurrence of brachiopod, ostracod, bryozoa, solitary coral, and pelecypods. Above this is 300 meters of evenly laminated buff and green colored siltstone. Overlying the siltstone member is 200 meters of fine to coarse grained quartzitic sandstone and conglomerate. clasts within the conglomerate are up to $10 \mathrm{~cm}$ in diameter and consists of siliceous rock fragments, monocryolaline (vein) quartz and feldspar. The Drem-Khed formation occurs as a possible klippe, however correlative strata has not been identified elsewhere on the island.

\section{Upper Devonian}

The Upper Devonian section (Berry suite of Ivonof, 1973)

has been identified in the southern part of the island, along the somnitelnayce and Khisknikov rivers. The thickness of this formation is at least 150 meters. It is a shallow water or tidal flat deposit consisting of calcareous fine grain sandstone, limestone, light green phyllitic shale with interbeds of gypsum up to 1 meter thick. A Frasnian age assignment for this unit was made on the basis of pollens found within the gypsum and by the presence of Lower Carboniferous Tournaisian brachiopods in the overlying deposits. 


\section{Carboniferous}

Carboniferous deposits (the Waring suite) are widely distributed on Wrangel Island. They occur in two thrust sheets which exhibit differences in facies. This suggest a major amount of foreshortening during thrusting. The Carboniferous section in the southern thrust sheet is a more complete stratigraphic sequence. It consists of mainly shales and shaly limestones. The Carboniferous section in the northern thrust sheet is incomplete with the Lower Carboniferous Visean and Tournaisian absent by non-deposition. The northern belt is mainly massive limestones.

In the southern thrust sheet, a basal conglomerate, which varies in thickness from 0 to 300 meters, transgressively overlies and onlaps the Upper Devonian section. Clast within the conglomerate are derived from the pre-Cambrian section and exhibit a schistosity which existed prior to erosion and re-deposition. This suggests a deformational fabric was developed in the Precambrian section during the lower Paleozoic. The development of this basal conglomerate section in the Lower Carboniferous on Wrangel Island is correlative to the deposition of the Kekiktuk conglomerate on the north slope of Alaska. Overlying the basal conglomerate is a 200 meter thick, light grey, shaly dolomitic limestone in which were found brachiopods and coral debris dated as late Visean.

Above this shaly dolomitic limestone is a 300 meter thick section of interbedded limestone and shale which contains the foraminifera: Pseudoendothyra aff. ovalis, Archaediscus itinerarus, A. krestovnikovi kokjubensis, and Planoarchaediscus spirillinoides. This assemblage is correlated to the Mamet zones 16 and 17 in the north slope of Alaska, and is thus equivalent to the lower Alapah limestone in the Lisburne group. The remainder of the Carboniferous section consists of 300 meters of sandy limestone with minor interbedded shale. Thickness of the limestone beds varies form 1 to 8 meters. The foraminifera found in this unit correlates to Mamet zones 18-20 in Alaska and are equivalent to the upper Alapha and lowermost Wahoo Limestone in the Lisburne group. The depositional environment of this unit is thought to be shallow marine and perhaps intertidal.

The Carboniferous section in the northern thrust sheet consists of a basal conglomerate 25 to 50 meters thick which was deposited on eroded Precambrian. It is overlain by 100 to 150 meters of massive light grey limestone. The foraminifera recovered from this limestone are correlated to Mamet Zones 18 and 19 in the upper Alapha Limestone in Alaska. Above the limestone is a 250 meter thick section of probable non-marine siltstone and shale with no faunal recovery. No equivalent non-marine section is known in Alaska.

\section{Upper Permian}

The Upper Permian section is exposed in the northern part of the island along the Herzvestnaya River where it transgressively overlies Upper and Lower Carboniferous. A basal conglomerate 0 to 15 meters thick contains mainly limestone clasts derived from the underlying Carboniferous section as well as clasts of quartz-sericite schist, quartzite and chert. The conglomerate is overlain by about 150 meters of interbedded phylittic shale and petroliferous limestone coquina containing numerous shell fragments of the pelecypods Kolymia and foraminefera. The age equivalent section in the north slope of Alaska is the Echooka formation which is a transgressive shallow marine sandstone and shale sequence. 
Triassic deposits are widely distributed across the southern part of the island where they unconformably overlie Permian to Devonian age section with an angularity of 15 to 20 degrees. The lowermost section consists of coarse grained, polymictic cross and ripple laminated arkosic and subarkosic sandstone with a thickness of 15 to 20 meters. Overlying this is a 800 to 1000 meter thick flysch sequence of alternating fine to medium grained arkosic sandstones and shales which have been interpreted to be marine turbidites. The age of this sequence is Norian which is equivalent to the shublik formation on the north slope of Alaska. No Ivishak equivalent is present.

\section{Igneous Rocks}

Intrusive igneous rocks on Wrangel Island are only observed within the Precambrian section. These occur as dikes and sills concordant with the structural fabric of the intruded rock. Igneous rock types are described as leucocratic granite, granodiorite porphyry, muscovite granites, and diabase. Potassium-argon age dating yields a wide range of ages from 575 MYBP to 115 MYBP with clusters of ages occurring near 400, 270 and 120 MYBP (Figure No. 2). It has been suggested by Fujita and Cook (in press) that the younger cluster of age dates reflects a resetting during a stage of thrusting.

\section{Structural Geology}

Detailed structural maps of the island are unavailable although I was able to examine a preliminary field map prepared by the 1986 soviet field party. A sketch map of major structural features was published by Kameneva, 1975 (Figure No. 3).

The major structural features on wrangel Island are east-west striking thrust faults which dip to the south at $20^{\circ}$ to $50^{\circ}$. Penetrative slaty clearage which is present in the entire section also dip to the south at $30^{\circ}$ to $50^{\circ}$ and is axial planer to numerous tight folds. Two major thrust sheets are recognized in the eastern and central parts of the island, three major thrusts are recognized on the western end of the island.

The amount of displacement on these thrust faults has not been established. As mentioned previously, the difference in facies in the Carboniferous units between the southern and northern outcrop belts suggests considerable displacement.

Strike-slip faults with a north-northwest trend have been mapped in the central mountains. These offset the thrust faults and all stratigraphic units except the quatenary. offsets are on the order of one to two kilometers in a right lateral sense. 


\section{WRANGEL ISLAND GENERALIZED STRATIGRAPHY}
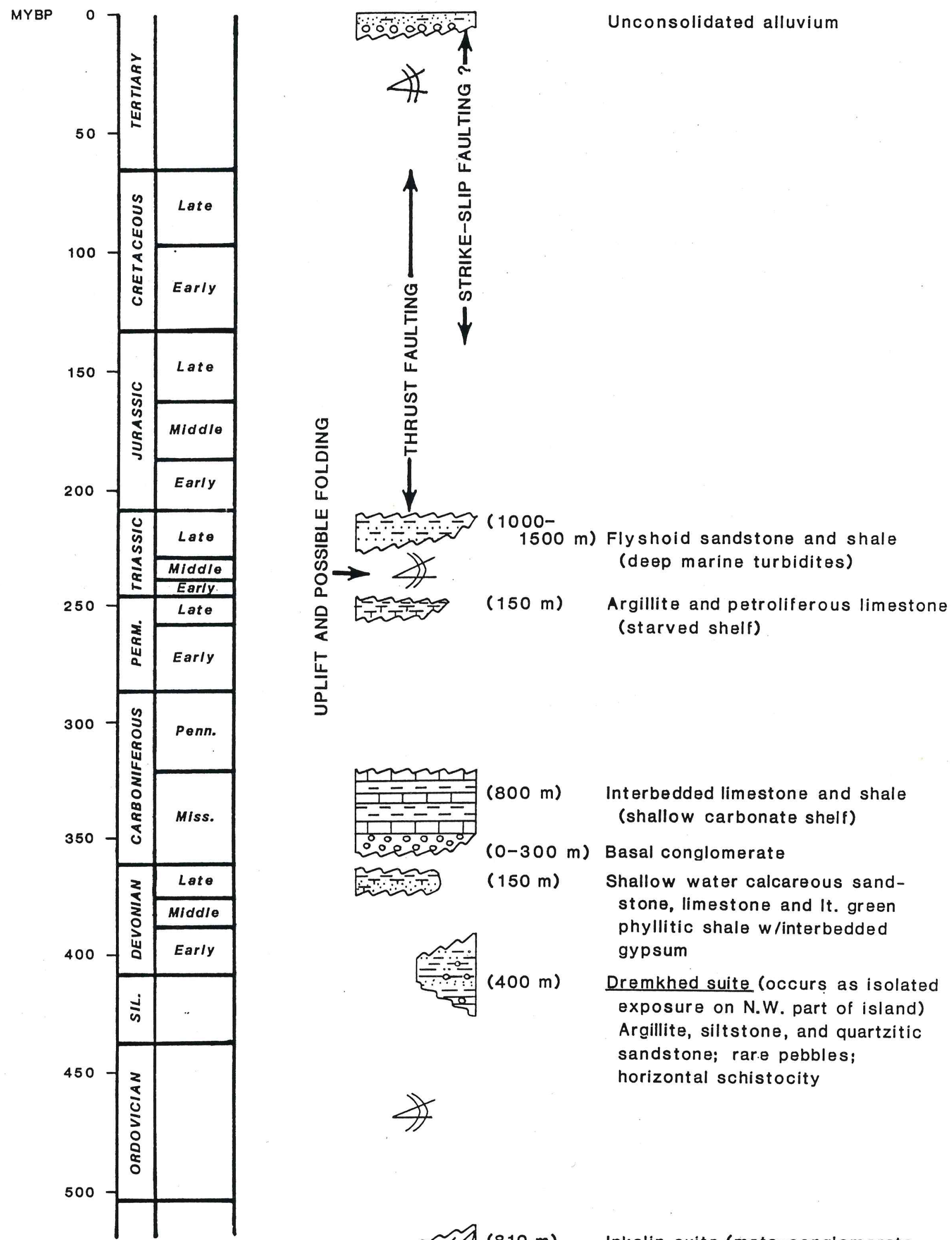

Interbedded limestone and shale (shallow carbonate shelf)

(150 m) Shallow water calcareous sandstone, limestone and It. green phyllitic shale $w /$ interbedded

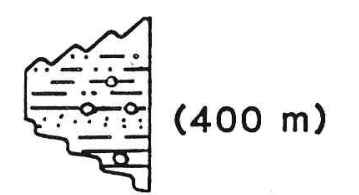
gypsum

Dremkhed suite (occurs as isolated exposure on N.W. part of island) Argillite, siltstone, and quartzitic sandstone; rare pebbles; horizontal schistocity

(810 m) Inkalin suite (meta-conglomerate meta-sandstone, meta-volcanics) Qtz-albite-muscovite-chlorite schist 


\section{DISTRIBUTION OF IGNEOUS AND METAMORPHIC AGE DATES}

(K/Ar dating from Ivanof 1973)

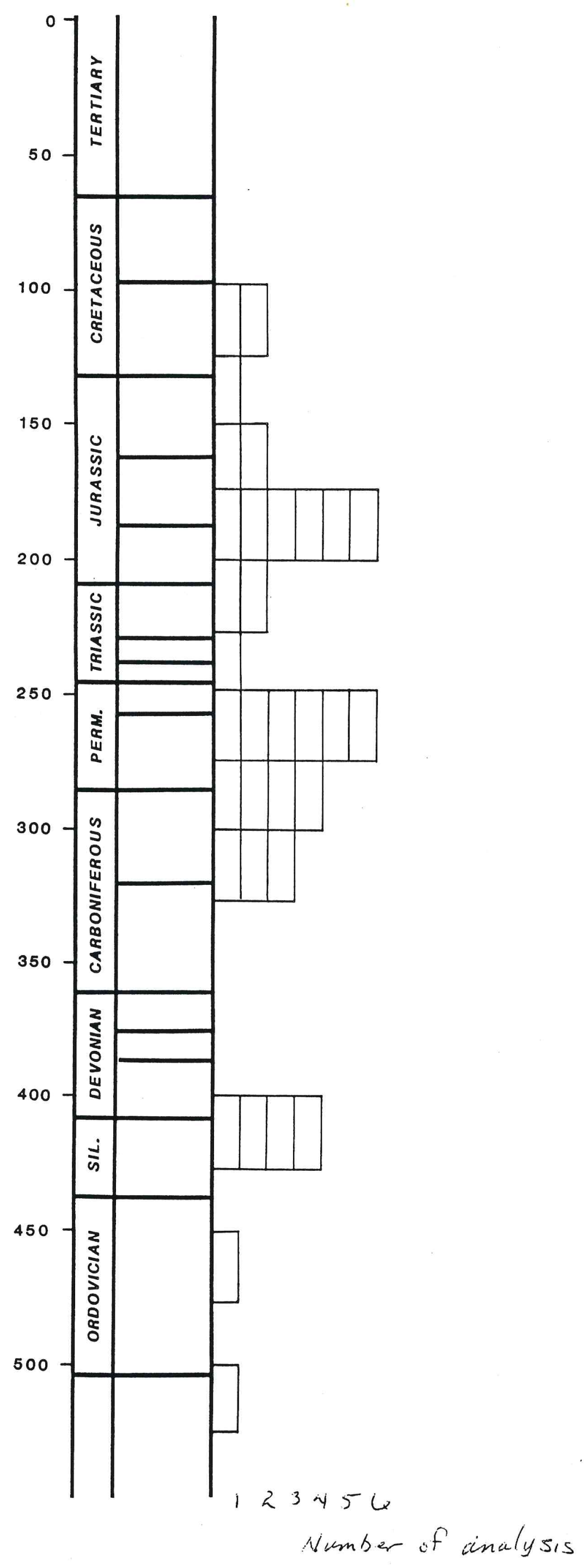




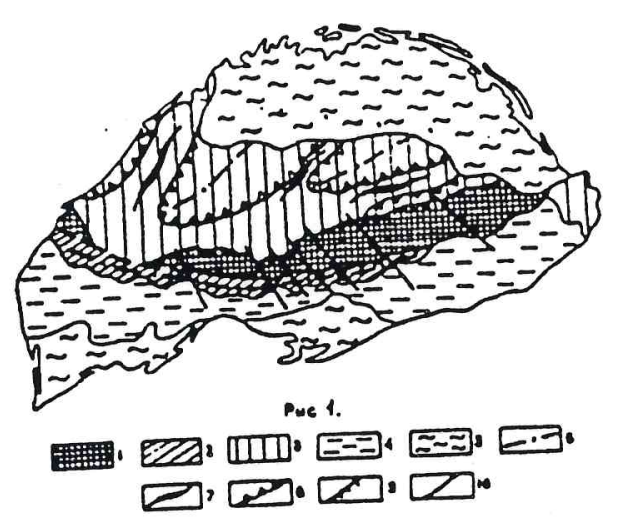

Fig.1 Structural-geological zones of the Wrangel island.

Central anticlinorium:

1. Axial zone formed by Upper Proterozoic and Low Cambrian deposits.

2. Southern zone formed by Upper Devonian -

- Upper Permian deposits, which are lineally folded.

3. Northern zone formed by Upper Silurian - Upper

Permian deposits all of which are brachyfolded.

4. Southern synclinorium formed by Upper Triassic deposits.

5. Neotectonical depressions filled up by Quaternary deposits.

6. Axes of the synclines.

7. Axes of the anticlines.

8. Brachyfolds.

9. Main thrust.

10. Faults.

Fig. 3 fran: Kamereva, G.I., 1985 
XIII. The Chukotka Structural-Facies Region

XIII. Chukotskaya strukturno-fatsialnaya oblast

From: Dagis, A. S., Arkipov, Yu. V and Bychkov, Yu. M., Stratigraphy of the Triassic System of Northeastern Region of Asia, Moscow, Izdatelstvo Nauka, 1979 
It occupies an area of a folded region of the same name on the coast of the East Siberian and Chukotka seas. The Triassic deposits are distributed very widely here and have been studied by many geologists.

G. Ya. Belik and also M. Ya. Gorodnitskiy (1959, 1963), V. V. Gulevich, D. F. Yegorov, Ya. S. Larionov, N. N. Neznanov, K. V. Paraketskov, A. I. Sadovskiy, G. M. Sosunov et al. investigated the Triassic period in the western part of the region, in the Malyy Anyuy and Rauchua river basins, A. V. Andrianov, Yu. M. Bychkov (1958, 1959), M. Ye. Gorodinskiy (1963), V. P. Pole, N. M. Samorukov (1975), I. V. Tibilov (1975), T. P. Khyuppenen et al. investigated the Triassic in the central part, east of Chaunskay Bay to the headwaters of the Pegtymel River, and V. P. Arkavyy, S. V. Blagodatskiy, V. P. Pole, V. K. Sadakov, K. S. Sukhov, Ye. P. Tarakanov et al. investigated the eastern part, in the Amguema and Ekiatap river basins and in the region of Kolyuchinskaya Bay.

The sections of the Triassic of the Chukotka region are characterized by a trimembral structure. The lower part, which corresponds approximately to the Lower Triassic, consists of green-colored masses of fine-grained chloritized sandstones and phyllitized argillaceous and chloride-argillaceous shales (the keperveyemskaya suite in the west, the gesmytkunskaya rock mass and the geuntovskaya suite in the central part and the iultinskaya suite and the lowermost strata of the amguemskaya suite in the east). It is $1-2 \mathrm{~km}$ thick.

The middle part of the section, corresponding to the Middle (?) Triassic, to the Carnian and in places to the lowermost strata of the Norian, is represented mainly by flyschoid rock masses (up to $2 \mathrm{~km}$ ) of grayish argillites, aleurolites and sandstones (the poneurgenskaya and pauktuvaamskaya suites in the west, the keveyemskaya, vatapvamskaya, relkivveyemskaya and other suites in the central part and the upper amguemskaya member and the mymlerenetskaya rock mass in the east). 
The uppermost strata of Triassic deposits $(1.5-1.8 \mathrm{~km})$ consist of dark rock masses of argillites, aleurolites and sometimes sandstones.

The level of study and the paleontological characterization of the Triassic deposits of the Chukotka region are weak. The Triassic section is represented by the following in the best-investigated western part in the upper reaches of the Malyy Anyuy and Rauchua (Figure 9).

The keperveyemskaya suite, divided into three members, is related to the Lower Triassic. The lower member on the Alyarmautskiy uplift is structurally concordant, but sometimes lies with angular unconformity on the vernitakveyemskaya suite of early-midale carboniferous age. The nizhnekeperveyemskaya member is made up of greenish-gray phyllitized argillaceous and flinty-argillaceous shales and aleurolites with interlayers of fine-grained calcareous sandstones and tuffsandstones: A stratum of tuffites and tuffs of diabases with interlayers of chlorite-argillaceous shales up to $40 \mathrm{~m}$ thick is found in the lower part of the section. The member is up to $800 \mathrm{~m}$ thick. No fossils were found in it. It is related to the indskian stage according to its position in the section below olenekskiy formations. It is not excluded that the lowermost strata of the member are Permian in age. The srednekeperveyemskaya member is formed primarily of greenish-gray fine-grained sandstones and sometimes calcareous sandstones. There are interlayers of aleurolites, flinty-argillaceous and flinty-chlorite shales, phyllites, tuffites and diabasic tuffs and sometimes carbonate concretions. The thickness of the member varies from 500 to $1,500 \mathrm{~m}$. The larger lower part of the section of the member includes numerous casts of Early Olenek posidonia, confined to the layers of argillaceous shales. They are represented by posidonia of the group Posidonia mimer Oeberg: P. Olenekensis Popow, P. christophori Popow, P. subtilis Bytschk. et Efim., P. sossunovi Bytschk. et Efim. and P. kulensis Bytschk. The remains of Ammonoidea are rare. These are 


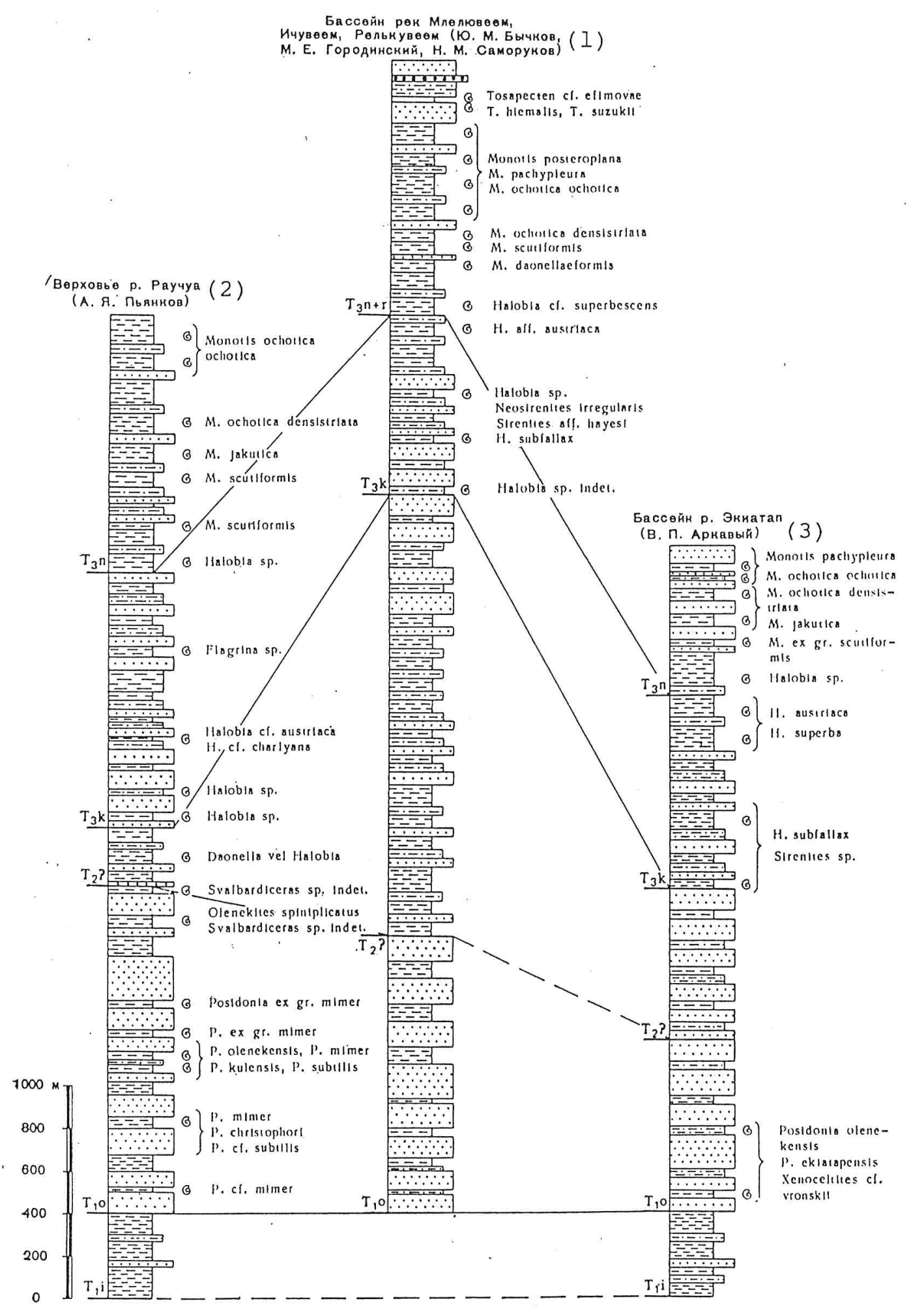

Figure 9. Comparison of Triassic Deposits of Chukotka StructuralFacies Region (See Figure 3 for Notations)

Key: 1. Mlelyuveyem, Ichuveyem and Relkuveyem river basin (Yu. M. Bychkov, M. Ye. Gorodinskiy and N. M. Samorukov)

2. Upper reaches of Rauchua River (A. Ya. Pyankov)

3. Ekiatap River Basin (V. P. Arkavyy) 
Paranorites? ultraradiatus Popow, Xenoceltites ex gr. kiparisovae Popow, Dieneroceras? sp. and Nordophiceras sp., which characterize the two lower zones of the olenekskian stage -- hedenstroemi and demokidovi.

The upper keperveyemskaya member $(300-450 \mathrm{~m})$ is lithologically similar to the middle member, but contains only single fossils. Eumorphotis sp. are noted in it among the bivalves and Olenekites spiniplicatus Mojs. and Svalbardiceras sp., typical for the spiniplicatus zone, are noted among the Ammonoidea.

The upperlying poneurgenskaya suite, determined by G. M. Sosunov among the keperveyemskaya suite, is shallow (300-400 m) and consists mainly of dark gray argillites anä sandy argillites with interlayers and benches of calcareous sandstones, carbonaceous-flinty shales and sandy limestones. No identifiable fossils were found in this suite. Poorly preserved single specimens of bivalves are represented by Halobiidae (Daonella or Halobia) of the Middle Triassic period or Carnian stage.

The pauktuvaamskaya suite, consisting of dark gray argillites, gray aleurolites and fine-grained sandstones, sometimes regularly interstratified between each other, lies above this deposit. There are interlayers of green and Bordeaux flinty-mica aleurolites at the bottom of the suite. The thickness of the suite fluctuates from 1,000 to $1,500 \mathrm{~m}$. The fossil content is rather rare. Ammonoidea Sirenites cf. hayesi Smith, Neosirenites cf. irregularis Kipar., bivalves Hallobia cf. indigirensis Popow, H. austriaca Mojs., H. cf. suessi Mojs. and H. aff. cordillerana Smith and Foraminifera Flagrina sp. are found in the lower member, while bivalves Halobia sp., H. Kolymensis Kipar., H. aff. charlyana Mojs. and Otapiria ussuriensis Vor. and Foraminifera Flagrina sp. are found in the middle and upper member. The mineral remains indicate that there are equivalents in the lower member of pentastichus and yakutensis zones of the Carnian stage; the middle member apparently corresponds to the Lower Norian zone of verchojanicum, 
while the upper member corresponds to the ussuriensis zone of the Lower-Midale Norian. Fossils, typical for the two lower zones of the Carnian stage, are not found in the western Chukotka region. Settling of these layers from the section is not excluded.

The pauktuvaamskaya suite is gradually replaced by the kuveyemkayskaya suite, within which dark gray argillites and aleurolites are sharply predominant, while gray fine-grained sandstones form individual interlayers. The thickness of the suite is approximately $1,000 \mathrm{~m}$. The fossils are rather numerous. Monotis scutiformis Tell., M. daonellaeformis Kipar. and Halobia sp. predominate in the lower part of the suite, while M. pinensis West., M. versicostata Bytschk. and Halobia cf. aotii Kob: et Ich. are found above it; Monotis jakutica Tell., M. ochotica densistriata Tell., M. ochotica ochotica Keys., M. zabaikalica Kipar. and M. pachypleura Tell. are numerous in the upper part of the suite, greater in thickness. Judging from it, the pauktuvaamskaya suite correlates with the scutiformis zone of the Middle Norian and the ochotica zone of the Upper Norian.

Argillites and aleurolites with Monotis ochotica Keys. and M. jakutica Tell. in the lower course of the Rauchua River with considerable stratographic unconformity overlap deposits of the middle keperveyemskaya member. The thickness does not exceed $100 \mathrm{~m}$ here. A rock mass $(900 \mathrm{~m}$ ) of calcareous sandstones, aleurolites and argillites with limestone lenses, which include a rather diverse combination of bivalves: Oxytoma czekanowskii Tell., O. mojsisovicsi Tell., o. zitteli Tell., Monotis ochotica Keys., M. Pachypleura Tell., M. cf. jakutica Tell., Tosapecten suzukii noricus Polub., Palaeopharus buriji Kipar., Lima sp. and Pleuromya sp., is deposited above. Since Monotis of group M. ochotica are not found throughout the section of this rock mass, it is not excluded that its upper part is related to the Upper Norian-Rhaetian zone Tosapecten efimovae. 
Lower Norian deposits, which seem to be deposited concordantly in Upper Triassic deposits, are observed only in the lower reaches of the Rauchua River and somewhat westerly in the Chukotka region. They are represented by dark gray argillites with Otairia originalis Kipar. and O. Limaeformis Zakh.

No reliable stratigraphic scheme of Triassic deposits has yet been developed to the east of Chaunskaya Bay, in the central part of Chukotka region, due to the abundance of fracture disturbances and the severe facies variability of the rock masses. Local stratigraphic schemes with their own suites and rock masses, usually characterized weakly faunistically and poorly correlated with each other, have been developed for some regions.

The gesmytkunskaya rock mass (600-800 m), consisting of aleurolites and mica-flinty shales with interlayers of sandstones, conditionally related to the indskiy stage and to the uppermost strata of the Permian, is not characterized paleontologically here. It is deposited structurally concordantly, but with large stratigraphic discontinuity on deposits of the Middle Paleozoic.

The upperlying deposits of the geuntovskaya suite, in which sandstones with carbonate concretions predominate, contain a significant fauna complex on the left bank of the lower course of the Pegtymel River. Ammonoidea occur from its lower member: Hedenstroemia cf. tscherskii Popow, Xenoceltites cf. kiparisovae Popow, Paranorites? ultraradiatus Popow, Anasibirites aff. multiformis Welter, A. aff. desertorus Smith, Dieneroceras aff. apostolicum Smith, Nordophiceras cf. olenekense Popow and Prosphingites sp., typical for hedenstroemi and demokidovi zones of the Lower olenekskiy substage. The remains of bivalves Posidonia mimer Oeberg, and P. Olenekensis Popow are also numerous here.

One find of Sibirites ex gr. eichwaldi Keys. from the spiniplicatus zone of the Upper olenekskiy substage is known in the upper member on the right bank of the lower reaches of the Kuvet River. 
The stratigraphic equivalent of the geuntovskaya suite in the Ichuveyem River basin are apparently the Ichuveyem rock mass and the etapvaamskaya suite, no fossils in which have been found (Figure 9).

The thick rock masses (up to $2,000 \mathrm{~m}$ ), frequently of flyschoid habit, related to the Midale Triassic here (the keveyemskaya suite, part of the vatapvaamskaya suite and so on), contain only vegetation detritus, the shells of Foraminifera of genus Flagrina and single Halobiidae, unidentified to genus. It is not excluded that a considerable part of them are of Carnian age.

The Upper Triassic deposits in the Keveyem River Basin and on the coast of the sea between capes Kiber and Shelagskiy are represented in the lower part primarily by rock masses of regularly alternating sandstones, aleurolites and argillites (the relkuveyemskaya suite, part of the vatapvaamskaya and mlelyuveyemskaya suites and so on) with total thickness of 800-1,200 m. Bivalves of the lower zone of the Carnian stage -- Halobia ex gr. atsuensis Tok. and H. ex gr. korkodonica Polub., jointly with Pectinidae and probably discophyllites, have been found in them west of mys Kiber. Ammonoidea: Neosirenites irregularis Kipar., Sirenites hayesi Smith, bivalves Halobia superba Mojs., H. austriaca Mojs., H. cordillerana Smith, H. cf. indigirensis Popow and so on, typical for pentastichus and yakutensis zones of the Carnian stage, are apparently collected higher. Halobia cf. austriaca Mojs., H. cf. aotii Kob. et Ich. and H. cf. superbescens Kittl, probably belonging to the Lower Norian verchojanicum and ussuriensis zones, have been found in the uppermost strata of the regularly alternating rock mass, where aleurolites and argillites are sharply predominant.

The upperlying, significantly aleurolitic-argillitic kuveyemkayskaya suite $(400-800 \mathrm{~m})$ contains numerous residues of Monotis of scutiformis and ochotica zones. Interlayers of gritstone and conglomerates are sometimes observed at the base of the suite and a stratigraphic hiatus, which encompasses scutiformis and ussuriensis time, is probable. 
The pyrkanayskaya suite (up to $300 \mathrm{~m}$ ), consisting of inequigranular sandstones with interlayers of argillites, gritstones and conglomerates, crowns the Triassic section in the basin of the middle course of the Mlelyuveyem River. Rare bivalves (Tosapecten suzukii Kob., T. subhiemalis Kipar., T. hiemalis Tell., T. efimovae Polub., Oxytoma ex gr. mojsisovicsi Tell. and so on) indicate its Lower Norian-Rhaetian age.

The Triassic section is strongly reduced on the Kuulskoye uplift, in the region of capes Billings and Yakan. Cases are known when shallow (up to $500 \mathrm{~m}$ ) Upper Carnian-Lower Norian (yakutensis or verchojanicum zones) or Middle Norian deposits lie directly on Middle Paleozoic rock. An outcrop from the Middle Triassic section is sometimes recorded on the uplift and Upper Triassic rock are superimposed on Lower Triassic rock.

The Triassic section is again more complete in the eastern part of the region, in the Amguema and Ekiatap River basins (Figure 9).

The iultinskaya suite, consisting of phyllitized greenish-gray argillaceous and carboniferous-argillaceous shales with interlayers of aleurolites and sandstones, lies at the base. It is up to $800 \mathrm{~m}$ thick. It is conditionally related to the indskian stage and to the uppermost strata of the Permian.

The overlying, essentially sandstone amguemskaya suite $(1,500-1,600 \mathrm{~m})$ is characterized in the upper part by rather numerous Posidonia: Posidonia olenekensis Popow, P. ekiatapensis Bytschk. et Efim. and P. subtilis Bytschk. et Efim., usually confined to layers of interformational conglomerates. Single specimens of Ammonoidea, represented by Xénoceltites cf. vronskii Popow, X. cf. kiparisovae Popow, Arctoceras sp. and Melagathiceras? sp., belong to the hedenstroemi zone, but the upper part of the Posidonia layers possibly corresponds to the demokidovi zone.

The upper amguemskaya member, which contains no fossils, is conditionally related to the Middle Triassic. 
The upperlying mymlerenetskaya and malomymlerenetskaya rock masses $(1,000-$ $1,100 \mathrm{~m})$ are represented by argillites, aleurolites and sandstones with vegetation detritus, shells of foraminifera Flagrina and by rare bivalves Halobia austriaca Mojs., H. superba Mojs. and H. aff. fallax Mojs. Single Ammonoidea belong to genus sirenites. These fossils may indicate with some conditionality the Late Carnian and Early Norian age of these rock masses. Whether the lower part of the mymlerenetskaya rock mass can be related tot he Early Carnian is unclear.

The chanaunskaya $(300 \mathrm{~m})$ and namnomkyvaamskaya $(150 \mathrm{~m})$ rock masses, occurring in the uppermost strata of the Triassic section, consist of argillites and sandstones. The number of the latter and the content of the vegetation detritus increases toward the top. Monotis of groups Monotis scutiformis and M. ochotica are present in the chanaunskaya rock mass, while only groups M. ochotica are present in the namnomkyvaamskaya rock mass. Upper Norian-Rhaetian and Lower Norian deposits are unknown in eastern Chukotka. 
Mineral Resources

Poleznyye iskopayemyye

From: Dagis, A. S., Arkipov, Yu. V. and Bychkov, Yu. M., Stratigraphy of the Triassic System of Northeastern Region of Asia, Moscow, Izdatelstvo Nauka, 1979 
A large number of deposits of various types of mineral resources of different origin -- from sedimentary and stratiform to numerous veined hydrothermal deposits of noble metals, tin, tungsten, polymetals, antimony, mercury and so on -- is concentrated in Triassic deposits of Northeastern Asia.

Fuel Minerals

Oil and gas. Productive gas-condensate pools have been discovered and prospected in Triassic deposits of the Vilyuysk structural-facies subregions. They are localized primarily in Lower Triassic deposits. Productive pools of gas and incidental condensate have been identified in the nedzhelinskaya suite of the indskiy stage (the Nedzhelinskoye deposit). The pools are concentrated in the tagyndzhinskaya suite and are shielded by argillaceous formations of the monomskaya suite of the Lower Triassic (the Sredne-Vilyuyskoye, Tolonskoye and Badaranskoye deposits). The gas condensate pool of this producing horizon in the Sredne-Vilyuyskoye deposit is located within the Khatanga-Vilyuysk oiland gas-bearing province. Productive gas and incidental condensate pools have also been prospected in the lower part of the monomskaya suite (the SredneVilyuyskoye deposit). A natural gas pool has been found in the sredne-Vilyuyskoye deposit in the Middle and Upper Triassic deposits of the Vilyuyskaya subregion.

The oil shows are also confined primarily to the Lower Triassic deposits of the Vilyuyskaya subregion. They are represented by oil films in influxes of stratal waters or by weak influxes, mainly light methane oils with low resin content and with the complete absence of asphaltenes. Weak influxes of oil have also been determined in Middle and Upper Triassic deposits in the sredneVilyuyskoye deposit.

The Leno-Anabarskaya structural-facies region is also an oil- and gasbearing region of Northeastern Asia. Oil and gas shows and a single oil deposit have been established in the Triassic deposits of the region. The major oil 
pool of the Nordvikskoye deposit is localized in Middle Triassic deposits, and small gas influxes have also been noted here.

Mineral coal. Only insignificant shows, represented mainly by carboniferous selvages and thin interlayers of carboniferous-argillaceous material in continental Middle and Upper Triassic deposits of the Western Verkhoyanye and Orulgan, have been found in Triassic deposits. Coal bands are known only in the Eastern Taymyr in the kuldiminskaya and nemtsovskaya suites (Migay, 1952), but not a single one of them reaches minable thickness (the thickness of the minable mass does not exceed $35-40 \mathrm{~cm})$.

Fuel shales. Shale shows are confined to olenekskoye deposits of the Omolonskiy mass, on the western and eastern limbs of the Dzhugudzhakskaya depression. The shale-bearing horizon is possibly distributed within the entire depression. Fuel shales comprise a bench of thin-schistose rock in Upper olenekskoye deposits approximately $10 \mathrm{~m}$ thick and comprise individual thin interlayers in Lower. Olenekskiy limestones. Interlayers of fuel shales with high ash content have also been noted in Midale Triassic deposits of the Dzhugudzhak River Basin. The similarity of paleogeographic situations permits one to assume the presence of interlayers of fuel shales in olenekskoye deposits of the southwestern part of the Omulevskoye uplift as well.

\section{Chemical Raw Materials}

Phosphorites. A large number of phosphorite shows, most of which have now been weakly studied, have been identified in Triassic deposits of Northeastern Asia. Carbonate-phosphate concretions of phosphorites are rather numerous among the thick dark Triassic rock masses of the Yana, Adycha, Indigirka, Kolyma and Omolon River basins and in the Northern Priokhotye and interlayers of phosphatized argillites, limestones or lenses and interlayers of phosphate conglomerates have been noted more rarely. It has been established that the most numerous shows of 
concretionary phosphorites are confined to Upper Aniziam, Upper Ladinian, Upper Carnian and Lower Norian deposits, while the conglomerates, consisting of rewashed and redeposited phosphorite concretions, are localized in Upper Norian deposits. Phosphorite shows have also been found in Middle Aniziam and Upper Norian-Rhaetian deposits. The shows in the Lower Triassic deposits are distinguished by low $\mathrm{P}_{2} \mathrm{O}_{5}$ concentrations and are probably. less promising.

Three interlayers of phosphorite conglomerates and argillaceous-calcareous phosphate-containing nodules (Taas-Ary, Buattar and other shows) are contained in aniziyskoye deposits in the lower course of the Lena River. The thickness of the conglomerates varies from 0.08 to $0.25 \mathrm{~m}$, while the $\mathrm{P}_{2} \mathrm{O}_{5}$ content in them varies from 3.2 to $6.9 \%$; the phosphoric anhydride content in the nodules and pebbles reaches $14-16 \%$. The amount of phosphoric anhydride does not exceed $0.3-3.6 \%$ in the bands of phosphate-containing rock. Another group of shows of the given region is confined to the lower part of Carnian deposits and is usually represented by a sandstone stratum up to $1.8 \mathrm{~m}$ thick with up to $15 \%$ argillaceoussiderite phosphorite nodules in them. The $\mathrm{P}_{2} \mathrm{O}_{5}$ content in the nodules varies from 5.6 to $14.4 \%$. Phosphorite shows are also known in this region in olenekskoye deposits. Bands of phosphate-containing conglomerates 0.1-0.15 $\mathrm{m}$ thick with phosphoric anhydride content up to 3.6 percent and argillite bands with numerous argillaceous-calcareous nodules of phosphorites with $\mathrm{P}_{2} \mathrm{O}_{5}$ content of up to $11.19 \%$ in the latter are observed in them (Tuchkov, 1966).

Indskian and Norian phosphorites have been determined within the AnabarOlenek interfluve. Indskian nodule phosphorites are distributed in the Buur and Nykabyt River Basin and form bands $0.2-0.3 \mathrm{~m}$ thick in the sandy-aleurolitic rock mass. The $\mathrm{P}_{2} \mathrm{O}_{5}$ content in the nodules is '13-27\% (Mishnin, 1975). Phosphorites in thin Norian sandstones are also known in this region. 
Separate shows of phorphorites are also known in indskian deposits of Orulgan, Western Verkhoyanye, Jularskiy and other regions of the Verkhoyansk folded region. They are represented by rewashed carbonate-phosphate concretions and by phosphate material in cement, and more rarely by bands of phosphate conglomerates. All these shows have been poorly studied.

Phosphate-carbonate concretions $5-30 \mathrm{~cm}$ in diameter in quantities up to 10-20\% have been found in Middle and Upper Triassic deposits in the Vtoraya Sentyabrskaya River Basin (Northern Priokhotye) in individual bands of calcareous argillites $0.1-2 \mathrm{~m}$ thick. The phosphoric anhydride content in the concretions varies from 2.5 to $32 \%$ Layers of phosphatized rock up to $0.8 \mathrm{~m}$ thick, containing 1.25-7.78\% $\mathrm{P}_{2} \mathrm{O}_{5}$, have been established in Upper Ladinian, Lower Norian and Upper Norian-Rhaetian deposits (Bychkov, 1975).

Strata 0.2-3.0 m thick, containing phosphorite concretions $2-15 \mathrm{~cm}$ in diameter in quantities of up to $10 \%$, have been found in Middle Triassic argillites in the western part of the Omolonskiy mass on the Dzhugudzhak River. The amount of phosphoric anhydride in the concretions varies from 18 to $31 \%$. The phosphorite-containing strata are separated by phosphate-free bands $0.2-5 \mathrm{~m}$ thick. The total thickness of Middle Triassic deposits is 40-45 m (Polubotko, Repin, 1975). Phosphorites are represented in Upper Triassic deposits by thin bands (up to $0.4 \mathrm{~m}$ ) of basal conglomerates, lying at the base of sections of ochotica and efimovae zones and consisting of rewashed Middle Triassic concretions. The phosphoric anhydride content in the pebbles reaches $32 \%$.

Phosphate-bearing Middle Triassic deposits are distributed very widely in all the depressions of the Omolonskiy mass, which permits high estimation of its prospects for finding Triassic phosphorites:

We note in conclusion that investigations of the quality and chemical properties of Triassic phosphorites (of the availability of phosphorus, of 
carbonate content and so on) showed their suitability for direct use as an effective fertilizer in the form of phosphate powder on acid, podzolic and peaty soils, widely developed in the agricultural regions of Northeastern Asia (Korneva, 1975).

\section{Metallic Minerals}

Ferrous metals. A rather large number of siderite bands up to 1-5 $\mathrm{m}$ thick has been found primarily in Upper Triassic deposits (the khedalichenskaya suite). of Western Verkhoyanye, Orulgan and adjacent territories. Some siderites contain a significant manganese impurity (up to manganese siderites). The siderite content in the strata reaches $95-99 \%$. Formation of these bands is related to formation of a Late Triassic weathering crust in the Late Triassic, on the areas of faulting, adjacent to the Western Verkhoyansk subregion. Redeposited brown iron ores with high manganese concentrations on the southern slopes of the Vilyuysk sineclise and on the northern slope of the Aldan shield should be linked to this epoch of crust formation. These brown iron ores underly everywhere deposits of the ukugutskaya suite of Early Jurassic age. They are represented by sheet-like beds of brown iron ores up to 1.5-3 m thick and approximately $1 \mathrm{~km}^{2}$ in area each. The ores consist of goethite, hydrogoethite, limonite and manganese oxides: manganite, pyrolusite and psilomelane. The ores contain an average of $32.5-37.7 \%$ iron and 5.8-8.5\% manganese. The manganese content in s.me types of ore increases to $17.98 \%$. The extensive areal distribution of manganous brown iron ores permits one to distinguish the Central Yakutian iron ore basin $3,000 \mathrm{~km}^{2}$ in area. This iron-ore basin with Late Triassic ores may be of practical significance in development of the iron ore deposits of southern Yakutiya (its ores can be used as alloying additives to nonmanganous magnetite ores of the Central Aldan and Charo-Tokkinskiy regions). 
Thin pools of oolitic argillaceous-goethite ores are known in association with multicolored argillites and aleurolites of the ust-kelterskaya suite of the Western Verkhoyanye and Orulgan. Leptochlorite oolitic iron ores have also been found in the gurimisskaya suite of the Anabar-Khatanga region.

Nonferrous metals. Shows and deposits have been found in Triassic deposits and there are also prospects for finding new shows and deposits of copper, lead and zinc.

The shows of native copper on the western slope of Orulgan (the upper course of the Begidzhan River) are confined to the roof of the effusive diabasic pool in the lower part of the ust-kelterskaya suite (the indskian stage). Strikes of copper minerals were observed in the rock of the diabasic cover of the ustkelterskaya suite in the Western Verkhoyanye (the right bank of the Nuory River). V. N. Osipov and N. N. Pushkar have determined shows of coppery sandstones during the past few years within the multicolored formation of indskian age (the nekuchanskaya suite) in the Southern Verkhoyanye, the Nitkan-Suntar interfluve). Silicified sandstone strata contain pockets with impregnation of copper minerals-covellite, chalcopyrite, malachite and azurite. The copper content in the pockets reached $2.5-2.8 \%$. It is remarkable that indskian sandstones of the Western, Eastern and Southern Verkhoyanye, Orulgan and the Kularskiy region are permanently enriched with copper (its content reaches $0.1 \%$ ). Shows of copper minerals are frequently observed in the locations of increased regional metamorphism of indskian rock, which is most probably related to mobilization of the ore mass from country rock.

A stratiform deposit of copper-tungsten series of formations is also known in the olenek deposits of Verkhoyanye. The mineralization here is localized in the stratum of scarnized limestones among argillite-argillaceous rock approximately on the boundary of hedenstroemi and. demokidovi zones. Copper mineralization 
of the deposit is related to sulfide mineral association, for which chalcopyrite, pyrrotine, sphalerite, stanine and so on (the Agylkinskoye deposit) are typical. The stratiform nature of this deposit has been confirmed by the fact that shows of the same elements as in the Agylkinskoye deposit are formed in adjacent sections when deposits of the given stratigraphic interval entered zones of increased regional metamorphism. Assaying the nonmetamorphic rock of the region of the deposit showed that it is constantly being enriched with copper and zinc (up to $0.1 \%$ ), which indicates the existence of a concentration of ore elements in the Lower Triassic deposits and the possibility of their mobilization during regional metamorphism.

Thus, in 1970, I. G. Volkodav observed strata of calcareous sandstones with impregnation of sphalerite in the Southern Verkhoyanye (Dyustachan River) among Norian argillite-aleurolitic formations (the ochotica zone). It is not excluded that some lead and zinc shows in other regions of the Verkhoyanye are of similar nature -- they sometimes indicate the affiliation of mineralization to specific strata. Geochemical sampling also shows that individual horizons of Lower Triassic and frequently of Upper Triassic deposits are enriched with lead and iron (Kularskiy rayon, Adychi River Basin and so on). In this case the shows under consideration are associated with effusive Triassic formations (bands of tuffs, tuffites or sheets) or are located in the immediate vicinity of them. other metals. Stratiform Agylkinskoye copper-tungsten deposits were indicated in Lower Triassic deposits. Moreover, the terrigeneous Triassic deposits of Northeastern Asia contain a large number of various endogeneous deposits of many metals. The subordination of some types of mineralization to rock masses of specific composition and age is found in thi's case, which is determined for the most part by the favorable physical and mechanical properties of Triassic rock for localization of Late Mesozoic endogeneous mineralization. The 
confinement of most shows and deposits of mercury to essentially sandstone rock masses of the indskian stage, the Middle Triassic of the Verkhoyan-Indigirka belt and so on, for example, is this type. Deep fault zones, sometimes established only from the characteristic features of variation of the lithological composition and thickness of Triassic deposits, are also important for determination of the principles of arrangement of endogeneous mineral resources. The Adycha-Tarynskiy fault, which controls the variation of facies and thickness of Upper Triassic deposits and the arrangement of antimony mineralization of Eastern Yakutiya, the system of Dulgalakhskiy faults, which controls the variation of the composition of Triassic deposits and the location of mercury shows and deposits and much more, are this type.

Construction Materials

Terrigeneous Triassic deposits are extemely widespread in Northeastern Asia and can be used if need be to manufacture many types of construction materials for the developing mining industry of this region of the USSR.

The argillaceous rock of the Yano-Kolymskaya and of the Polousnenskaya facies regions may serve as raw material for keramzit production. Triassic argillites swell upon preliminary heating $\left(150^{\circ} \mathrm{C}\right)$ and the swelling factor reaches 2-7 at $1,100-1,200^{\circ} \mathrm{C}$. The volumetric weight of this rock is from 800 to $200 \mathrm{~kg} / \mathrm{m}^{3}$. The reserves of this rock are essentially unlimited and can be prospected in many regions.

Many Triassic types of rock can be used as construction stone. Norian coquina-limestones several tens of meters thick in the upper reaches of the Armani and Viligi rivers can be used to manufacture raw cement. Lower olenek limestones, known in many regions of Northeastern Asia, meet these same requirements. 
Large mineral dye deposits (Vendyavkiri and Kuolandskoye), confined to Lower Triassic deposits, in which porcelain clay shows are also concentrated, have been discovered in the Buur River Basin. Ochre strata are localized in the upper zone of the developed weathering crust of indskian age. They consist of weathered sandstones, aleurolitic clays and the ochres themselves. The thickness of the ochre strata reaches 1-2 m. Dye clays are related to higher quality ochres and their geological reserves number in the tens of millions of tons. 
THE GEOLOGICAL STRUCTURES

oF THE CENTRAL PART OF THE WRANGEL ISLAND.

Understanding the geology and the structure of the Wrangel island, a unique large island in the Chukchi Sea, has important scientific and practical significance.

Field work in the years 1970 - 1972 provided new biostratigraphical data about pre-mesošoic deposits located there and allowed previous hypotheses about the island's structure to be re-evaluated. The oldest structure of the Wrangel island is a metamorphic complex in the central part of the island. The use of mineralogy, metamorphical conditions, and the presence of different associations of the acritarch, microphytolith, and algaes, has allowed this metamorphic complex to be divided into the Gromevskaya suite, the Inkalinskaya suite, the Naskhokskaya stratum. The Gromovskaya suite, the oldest suite, is generally formed by amphibolite schist, epidote-amphiboiltes schist, amphibole-biotitechlorite schist, and quartz-biotite-chlorite schist, which were formed during regional metamorphism of the basic, neutral and acid rocks under conditions promoting epidote-amphibolite and greenschist facies development. The coarsegrained metamorphosed tuffstones, the arkosic sandstone, and rare (solitary) lenses and beds of the Garnet-epidote-diopside marbles are a subordinate part of this suite. Also, there are subconcordant and concordant intrusions of the re - granite-porphyry and gabbro-diabase. The Gromovskaya suite is more than $2,000 \mathrm{~m}$ mat in thickness. In the top of the section of the Gromovskaya suite abundant acribe tarch and solitary microphytoliths, which have been dated as middle-late Riphean, have been found (conclusions by L.N. Ilchenko and V.E. Milshtein).

The overlying Inkalinskaya suite with metaconglomerates at the base, is composed of arkose and quartz-feldфspar metasandstones and metatuffstones, actinoliteepidote-chlorite schist, quartz-albite-muscovite-chlorite schist and quartzalbite-sericite schist, and is $810 \mathrm{~m}$ in total thickness. According to the section, there is a predominance of terrigenous deposits. The effusives, most of which are acid in composition, coincide with the lower part of the section. The metamorphism of the rocks is of greenschist facies. The Inkalinskaya suite has the typical characteristics of the Vend* stage throughout the entire section (conclusions by L.N. Ilchenko). L but no F-innas.

* Vend stage - according to the Russian stratigraphy, the Vend stage correspond to the youngest Pre-Cambrian sedimentary deposits, which overlie Upper Proterozoic (Upper Riphean) deposits. 


$$
\text { - } 2 \text { - polymactic with } g^{t}+g^{t}, t-c l a s t:
$$

The Inkalinskaya suite is covered by metamorphic ${ }_{n}$ conglomerates, which lief at the base of the Naskhokskaya strata. This strata is formed by, phylitite, of , quartz, quartz-sandstone and is not less than $800 \mathrm{~m}$ thick. The age of the strata is determined by its position in the section and the presence of Early Cambrian acritarch, microphytoliths and algaes (conclusions by L.N. Ilchenko and V.E. Milshtein).

a Prims In the farthest NW part of the island (Drem-Khed Mountain), and also in the interfluve between the Neizvestnaya river and the river Krasnly Flag (Grobnitsa Mountain) are Uper Silurian-Lower Devonian depostts if the Drem-Khedskaya formation. This formation is composed of argillite, aleurolite and quartz-sandstone. Conglomerates with quartz gravel lay on the on-the base. The thickness of the formation is not less than $400 \mathrm{~m}$. The age of the Drem-Khedskaya formation is determined by a numerous faunal remains of brachiopods, ostracodes, bryozoans, corals, and pelecypods.

- In the southern part of the island in the Somnitelnaya river headwaters and in the upper parts of Khishnikov river, Upper Devonian deposits are shown. In the Somnitelnaya river headwater, the deposits are formed of calcareous

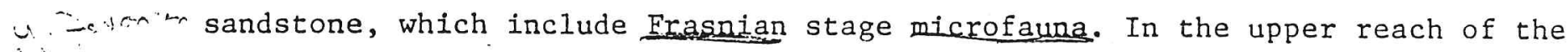
Khishnikov river, these deposfts are probably correlated to a higher horizon of the Upper Devonian deposits, formed of sandstone, limestone, and set with interloyers of gypsum.

brachiopods in the overlying deposits. The thickness of the Upper Devonian is not less than $150 \mathrm{~m}$.

- The Carboniferous deposits are represented by the Lower and Middle stages. Upon consideration of the differences in completeness, the character of the section, thickness and morphology of the folded structures to the north and south from the central mountains, we distinguished northern and southern structural-facial zones. In the southern structural-facial zone the Lower Carboniferous deposits with thin basal conglomerate lenses transgessively overlie the Upper Devonian. Clayey limestones with a thickness, of $200 \mathrm{~m}$, which containg no Tumno: inbrachiopods and corals of the Tournalsian - Vizean stages, overlieg the conglofincos Exan $(\therefore)$ merates. A strata formed of limestone and sohale with a thickness of $300 \mathrm{~m}$, lies comformably over the limestone strata. In the northern structural-facial zone the Lower Carboniferous deposits lie discordantly over the Lower Cambrian a on Gromev deposits. Conglomerates and gritstones with a thickness of $25-50 \mathrm{~m}$ are $10 \mathrm{cated}$ at the base of the section and overlying them is a limestone unit with a thickness of 100-150 m, which contains shale interlayers. The limestone unit also con- 
tains coral accumulations in a few places but is rare to find brachiopods. The limestone unit possibibly relates to the Lower Namurian stage. The limestone unit is covered by a shale unit with a thickness of 200-250 m, which contains rare interlayers of 1imestone. No faunal accumulations have been found but it is possible to relate it to the Upper Namurian because of its position in the section.

The southern structural-facies zone is represented in the Middle Carboniferous by a unit approximately $300 \mathrm{~m}$ thick of interbedded limestone and shale. A gradational lower contact exists between the underlying strata and these deposits of the Middle Carboniferous. A lower Bachkirie* stage complex of foraminifers was found close to the base and upper Bachkirie* and Moscovien* stage foraminifers were found close to the upper part of the strata. In the northern zone, a limestone strata, about $250 \mathrm{~m}$ thick, with interlayers of conglomerate in the middle part, overlies the Lower Carboniferous schist strata. In the lower part of this unit there are interlayers of sandy limestone, with bioherms containing brachiopods and rare goniatites. The bioherms are highly silicified by bryozoan algae. In the upper part of the limestone strata it is common to find late Bachkirie-early Moscovien age foraminifers.

The Upper Permian deposits transgressively overlie the Lower and Middle Carboniferous hortzons. It is possible to observe them in the lower reaches of the Neizvestnaya river, in the Nashaya hill, and in the middle reach of the Mamontovaya river. The Upper Permian deposits which are about $150 \mathrm{~m}$ thick, are represented by argillites and organogenic limestone. Conglomerates with a thickness of $15 \mathrm{~m}$ occur at the base of the Upper Permian deposits in the Neizvestnaya not observation khisinhikov Riner river. The limestone contains numerous pieces of pelecypods (Kolymia genus) and foraminiferes. These determine the age of tha limestone to be of the Dzhigdalin

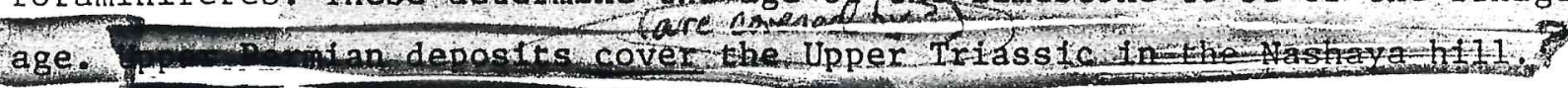

The Upper Triassic deposits are situated in the southern part of the island, where they transgressively overlie older deposits. These deposits have a thickness of 1,000-1,500 $\mathrm{m}$ and are represented by interbedded sandstones, aleurolites, ? and argillite. The age is determined by numerous faunal remains.

The nonconsolidated Quaternary deposits are distributed over all the island. Inthe mountainous parts of the island eluvial-colluvial deposits are common.
* Bachkirie stage - according to the Russian stratigraphy, this stage corresponds to the Lower Carboniferous age. These sections are the Namurian $B+C$ and the lower part of the Westphalian stages.

* Moscovien stage - according to the Russian stratigrapgy, this stage corresponds to the Upper Carboniferous deposits. These sections are the upper part of the Westphalian stage(Westphalian C+D) 
Alluvial-lacustrine deposits cover the southern littoral plain and Tundra Academia.

The most important structural element in the region is the Central Anticlinorium with an almost latitudinal axlal trace. This structure is formed of sedimentary, metamorphic, and magmatic formations of Proterozoic and Paleozoic ages. In the southern part of the territory the anticlinorium is connected with the southern synclinorium. In the anticlinorium core the oldest Upper Proterozoic metamorphic, sedimentary, and magmatic rocks of the Gromovskaya suite are exposed. To the north and south from the axial zone of the anticlinorium, the rock types in the limbs of the anticlinorium slowly change from Upper Proterozoic age in the center to Permian at the outs1de. The anticlinorium is asymmetric and overturned to the north. In the anticlinorium, smaller folds are also overturned to the north. The anticlinorium structure has been significately changed by fault mouvements. In the formation of the anticlinorium is possible to differienciate three zones: axial, northern, and southern (fig.l).

The northern border of the axial zone is the main thrust, and the southern is a fault, which follows along northern limits of the Upper Devonian deposits. The axial zone is formed by Upper Proterozoic and Lower Cambrian deposits. It has an anticline structure. The folded intrusions of Late Proterozoic graniteporphyry and gabbro-diabase are confined to the anticline's arch. The anticline of the axial zone is divided into blocks by a system of diagonal and transversel faults. The most uplifted structural blocks are the Sovetskaya and Gromov' Mountains, and also the peak of Berry Mtn. They have the most complete stratigrphic sections of the Proterozoic and Cambrian deposits. The interior structure of some blocks is very complicated and has not been fully explaned because of lack of outcrops. Visible in outcrop are linear isoclinal folds which have limbs up to 5-8 $\mathrm{m}$. The strike of the strata do not deviate from the axial zone.

Thus, the linear character of the large-scale folds is not in doubt. Except for inversion of folds to the north, other morphological characteristics of the largescale folding of the Proterozoic and Cambrian strata in the axial zone is unknown. The latitudinal fault located near the upper reach of the river Neizvestnaya and Lagerniy creek divides the axial zone on two branches: northern and southern. The northern auxiliary fault changes its strike from the sublatitudinal direction to the NE, while the southern auxlliary fault mantains its sublatitudinal strike. In the joint zone of these two auxiliary faults, in the cores of synclinal folds of the transitional type, Carboniferous deposits are exposed, which have a structural disconformity with the underlying Proterozolc deposits.

In the upper reach of the river Neizvestnaya a basin-type of syncline with the 


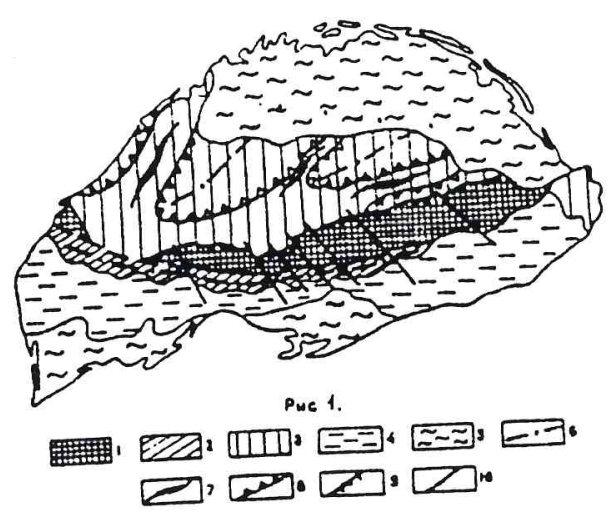

Fig.1 Structural-geological zones of the Wrangel island.

Central anticlinorium:

1. Axial zone formed by Upper Proterozoic and Low Cambrian deposits.

2. Southern zone formed by Upper Devonian -

- Upper Permian deposits, which are lineally folded.

3. Northern zone formed by Upper Silurian - Upper

Permian deposits all of which are brachyfolded.

4. Southern synclinorium formed by Upper Triassic deposits.

5. Neotectonical depressions filled up by Quaternary deposits.

6. Axes of the synclines.

7. Axes of the anticlines.

8. Brachyfolds.

9. Main thrust.

10. Faults.

Fig. 3 from: Kameneva, G.I., 1985 
length of the 1 imb being $2-2,5 \mathrm{~km}$ has been mapped. The eastern $1 \mathrm{imb}$ of the fold has an angle of $\mathrm{d} f \mathrm{p}$ of $50^{\circ}$, and the western limb of the fold has a $40^{\circ} \mathrm{dip}$. The syncline has a concave hinge and is made more complex by having undergone flexure. In the core of the fold are exposed Middle Carboniferous deposits, and on the limbs are exposed deposits of the Namurian stage. The syncline of the upper reach of the river Clark is considered to be the same type of syncline as described above. A narrow slit-like syncline with limbs approximately $0,5 \mathrm{~km}$ in length has been found on the upper reach of Lagerniy creek. The syncline is $10 \mathrm{~km}$ in length. Its southern limb is terminated at the fault.

The northern structural zone is situated between the zone of the main thrust and the northern border of the study area. The northern $11 \mathrm{mb}$ of the anticlinorium and the northern structural zone are composed of Silurian-Devonian, Namurian, Middle Carboniferous, and Upper Permian deposits. The folding style of the northern zone is characterized by series of the brachysynclines, which are divided by narrow anticlinal ridges. Synclinal folds are displaced in a echelon-manner to the NE direction and lie discordantly with the structures of the axial zone. The strike of the synclinal axes differs $20^{\circ}-30^{\circ}$ from the strike of the axial zone structures. The limbs of the brachysynclines are $10-15 \mathrm{~km}$ in size. The strike of the axis of the syncline on the left-hand side of the Neizvestnaya river is directed to the north. Upper Permian deposits are exposed in the syncline's core, and Namurian deposits are exposed in the limbs. In the core of syncline located in the interfluve of the rivers Neizvestnaya and Krasniy Flag are exposed Middle Carboniferous deposits; Namurian deposits are exposed in the limbs. In the extreme $\mathrm{NE}$ of the study area, in the upper reach of the river Naskhok, the limb of the syncline is covered by an allochtonous limb of the thrust. Along the northern slopes of the Central Mountains, in the upper reach of the river Krasniy Flag, and, also, in the interfluve of the rivers Neizvestnaya and Khrustalnaya, only the syncline's limbs has been found. They are covered by Upper Proterozoic deposits, which were thrusted in a northern direction. Strata which form brachysynclines in the area between klippes and thrust show fine corrugation with a northern vergence. The amplitudes of the corrugated folds varies from dozens of the centimetres to several meters. Corrugation is, probably, the result of the movement of the limb of the thrust on the autochthon.

In the southern structural zone, which represents the southern limb of the Central anticlinorium, the Upper Devonian, Tournaisian-Vizean, Namurian, Middle Carboniferous and sometimes Upper Permian deposits are exposed. The southern limits of this zone coincides with the northern limits of the areal 
extent of the Upper Triassic deposits. Paleozoic rocks of this zone are deformed in a system of the IIneal folds overturned to the north. The best exposure has a lineal sublatitudinal syncline with the axis passing through the upper reaches of the river Khishnikov and Khrustalniy creek. This fold has been traced as far as $50 \mathrm{~km}$. The limb $1 \mathrm{~s} 7-9 \mathrm{~km}$ in length and in the basin of the river Nashaya, the $11 \mathrm{mb}$ is $2-3 \mathrm{~km}$. The axis is gently undulating but is generally close to horizontal. The northern limb of the syncline is steeply dipping with the angles of dip sometimes near vertical. The angles of the dip of southern limb are close to $30^{\circ}$. Middle Carboniferous or Upper Permian deposits are exposed in the core of the fold, with the Lower Carboniferous and Upper Devonian deposits exposed in the limbs. The structure of the southern zone is dissected by numerous diagonal fractures and complicated by small isoclinal folds with northern vergences, which emphasize the direction of the movement of the allochthonous limb of the thrust.

As has been noted above, in the southern part of the study area the limb of the large synclinorium, which meshed with the Central anticlinorium, is exposed. This limb is formed of Upper Trtassic deposits. The composition of this structure is not clear due to insufficient data. Against a abckground of the monoclinal folding of the layers in the limb of the 11neal latitudinal structure, there are numerous lineal folds with the angles of dip of the limbs of $25^{\circ}-30^{\circ}$ and with the length of the 1 imbs up to $1 \mathrm{~km}$. In addition, there are very small fault-line folds, ovrturned to the north. It seems, that small folding in the Triassic deposits has a linear character and is accompanied by numerous small thrusts and upthrow faults, which are subparallel to the axes of the folds. The faults are widely distributed and most numerous in the axial and southern zones of the Cental anticlinorium. They are divided into thrusts and faults on the basis of genesis and morphology. The first time thrusts were noted on the Wrangel island by L.V.Gromov in 1939. But they were forgotten for a long time, and only recently have O.N.Ivanov and S.G.Bialobzheskiy given attantion to the leading role that the thrusts play in the makeup of the island's structure. A large thrust has been observed in central part of the 1sland. It is confined to the border of the axial and northern zones of the anticlinortum. The length of the thrust along the northern slopes of the Central and Mamontovie mountains is more than $65 \mathrm{~km}$. The thrust has been characterized by a sublatitudinai strike, which is the same as the strike of the folds. The shear displacement occures in the $\mathrm{S}$ and $\mathrm{SE}$ directions with the angle of the dip being $30^{\circ}-50^{\circ}$, and in eastern part of the area the angle of the dip is $20^{\circ}-30^{\circ}$. The thrust has undulating profile with festoons and reflects the character of the relief dis- 
section. In the $n 1$ lochthonous limb of the thrust, which forms the most elevated parts and ends with the bench on the northern slopes, metamorphic rocks of Upper Proterozolc age were found. The authochthonous part of the thrust, which form the basis of the benches, were formed by the Namurian and Middle Carboniferous deposits. Near the upper reach of the river Krasniy Flag in the allochthonous $11 \mathrm{mb}$ a "tectonic wlndow" with the Middle Carboniferous limestones of the autochthonous limb on the surface has been formed by erosion. In the NW part of the nrea, on the Pervaya mountain, klippes have been mapped at elevations of $343,0 \mathrm{~m}$ and $432,0 \mathrm{~m}$. They have oval plans and are elongated in a NE direction. These klippes form cliffs with the bench on the NW end and dip at low angles to SE. The klippes are accompanied by a zone of brecclated rocks with a thickness from 1,5 to $5 \mathrm{~m}$. Zones of brecciated and mylonitizated rocks with thickness of some meters are also related to the thrust-fault plane. Along the northern slops of the mountain Inkaly, in addition to brecciation, there are silifications and formations of ochers (oxidation). In the deposits of the autochthonous limb of thrust on the northern slopes of the Gromov mountains, fine corrugation, plication, and small drag folds have been observed. Also was observed, that the strikes of the allochthonous and autochthonous limbs do not coincide. The parallel displacement by the thrust was generally from the south to the north. The klippes are located at distances of $8-10 \mathrm{~km}$ from the northern slopes of the central mountains, suggesting that the amplitude of the thrust was more than $10 \mathrm{~km}$. It has been determined recently that the youngest deposits of the autochthonous limb are Middle Carboniferous, therefore the thrust could be formed only in Post-Middle Carboniferous age. Because the brachyfolds of the autochthon were formed by Upper Permian deposits, it could be that the thrust had occured in the Mesozoic, probably in Post-Upper Triassic time.

The faults are well presented in the area. There are two types of faults: 1. diagonal faults, conjugated with the thrust, and 2 . transversel faults with a general NW strike. The thrust located along the northern slopes of the Inkaly mountain is connected with the sublatitudinal fault, which has a rectilineal form in the plan view. The same kind of fault has been observed along the northern slopes of the Sovetskaya mountain and the peak of Berry. It is defined by depression of the landforms. The fault lines can be easily seen in air-photos. Overturned deposits and glide planes were observed in the fracture zone. along the southern slopes of the Central mountains the fault can be traced as far as $30 \mathrm{~km}$. It is defined by depression in the relief. This fault has a stepped contour because of the younger transverse faults, which cross cut it. The joining of the thrust and faults suggests that they are probably of the same 
age. The transverse faults are most common in the area. They are well defined in rellef and easily interpreted from air-photographs. This type of faults has been used by the rivers of the island as dratnage paths and therefore often form part of the river valleys. The transverse faults are characterlzed by different amplitudes of the displacement (from some meters to hundreds meters) and different length. Most faults have NW strikes. The dislocations mentioned above affect not only Proterozoic, but also Paleozolc and Mesozoic deposits as well. The age of these dislocations has to be considered as Post-Upper Triassic, but younger than the thrusts and diagonal faults, because the transverse faults were displaced by them.

Thus, there are three structural levels on the island, which represent three major tectonical cycles(fig.2).

The lower level is formed by Upper Proterozoic and Lower Cambrian deposits. This level is characterized by:

- well developed compressed lineal folds

- the metamorphism up to amphibolite facies

- effusive series and genetically related to them hypabyssal folded intrusions of the gabbro-diabase and granite-porphyry.

Total thickness of the lower structural level is more than $3,600 \mathrm{~m}$. The formation of the lower structural level is probably related to an eugeosyncline. Moreover, Upper Proterozoic deposits of the lower structural level probably correspond to the formation of porphyries. Terrigenous deposits of the Cambrian with the conglomerates at the base can be related to the orogenic process. The structure of the lower level was, probably, formed at the time of the Baikalian tectonical cycle. The long period of the peneplanation of the Baikalian inversive geosyncline has been reflected in the large stratigraphic break from Middle Cambrian to Upper Devonian in the south and from the Middle Cambrian to Upper Silurian in the north. From the structural-formational point of view, the lower structural level of the Wrangel island has to be related to the ancient foundation of the Mesozoic folded structure. Indeed, it consists of intensively folded strata of the Baikalian cycle, the earliest cycle on the island. Middle and Upper Paleozoic deposits are present as a thin cover, which had,probably, been formed under quasi-platform conditions.

The middle structural level is separated from lower level by a structural and stratigraphical disconformities and is composed of Paleozoic deposits from Upper Silurian to Permian ages. The structure of this level is non-uniform. This non-uniformity has allowed the anticlinorium to be divided into three structural zones, which has been described above (axial, northern, and southern). Generally, 


\section{Fig.2 Composite stratigraphical column} of the Wrangel island.

1. Terrigenous-volcanogenic formations.

2. Terrigenous deposits.

3. Carbonaceous deposits.

4. Terrigenous-carbonaceous deposits.

5. Terrigenous flisch-type deposits.

6. Interruption in sedimentation.

7. Regional metamorphism.

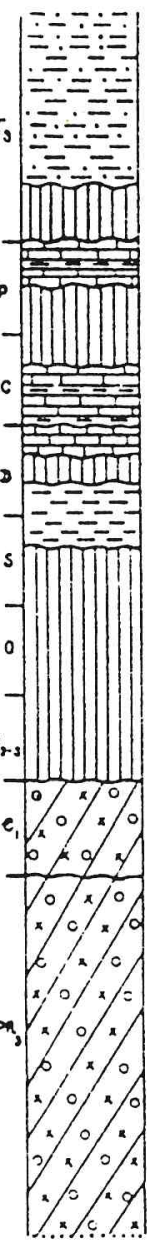

미음

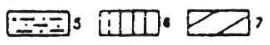


the middle structural level can be characterized by:

- domination by the carbonaceous facies in the Paleozoic sections

- small thickness of the sedimentary deposits $(1,100-1,200 \mathrm{~m})$

- existence of the quartzose sandstone (sandstones of the Drem-Khed suite) on the facial sections

- frequent recurrence of conglomerates in the Paleozoic sections, which indicate frequent changes of uplift and subsidence

- the absence of magmatic formation

- development of an intermediate type of the folds (brachyfolds, basin-like, and slit-like folds on the north, and lineal folds dipping at low angles in the south).

It is obvious, that the middle structural level has to be related to quasiplatform cover, which had been formed during a period of the relative stabilization of the tectonical conditions. The differences in the structures of the northern and southern zones of the middle structural level can be explained in two ways:

1. By the differences in the quasi-platform conditions from the both sides of the permanent anticlinorium of the ancient foundation, which was influenced by the Hyperborean platform on one side, and Novosibirsko-Chukchi fold system on the other.

2. By differences in the structure of the thrust's limbs (if one imagines the axial zone of the anticlinorium as a gigantic allochthon) with the roots more far to the south. The lineal folds would be formed on the allochthon limb, but at the same time the typical quasi-platform structures would be formed in the north.

This problem can not be resolved at the present time due to the relatively small study area.

The upper structural level is represented totally by Triassic deposits of the Southern synclinorium and is separated from the middle level by a structural and stratigraphical disconformity. The noticeble sharp increase in thickness of the sand-schist strata of the Late Triassic could probably correspond to flysch-type formation. The thickness of the terrigenous deposits of the Late Triassic is $1000-1500 \mathrm{~m}$, what is about the same thickness of the deposits through all Paleozoic (without the Lower Cambrian). Apparently, the upper structural level signifies by it self the begining of regeneration of the geosyncline regime of the Wrangel island. The folding structures of the Upper Triassic deposits have a lineal geosyncline character and their formation has been accompanied by thrust movements. The last tectonic cycle of the island was, 
Kameneva G.I.

\begin{tabular}{llllll} 
TECTONIC & SETTING & OF & THE & VRANGEL & ISLAND \\
\hline AND & ITS & STRUCTURAL & RELATIONSHIP & WITH \\
\hline
\end{tabular}

ALASKA IN PALAEOZOIC.

Vrangel island is located on the shelf of the Arctic ocean and lies between Eastern Sibirian and Chukchi seas. Its location is close to Alaska.

For a long time, the only geological information on Vrangel island available were field data of Gromov L.V. and Kiryushina M.T. ( in $30^{\text {ties }}$ ), and of Tilman S.M. and Ivanov $0 . N$. in the $60^{\text {ties }}$. The lack of geological information and geological maps permited the interpretation of the geological setting of the area in different ways. Some researchers related Vrangel island to the Chukchi Mesozoic folded area; others included it in miogeosyncline, or considered the island as some particular zone of the Arctic.

Geological field work carried out by researchers of the NIIGA in 1970-1972 led to the acquisition of more specific information about the geological history of the Vrangel island.

Vrangel island is made up of Proterozoic, Palaeozoic, and Mesozoic formations. The oldest one are Middle-Late Proterozoic formations which were found in the central part of the island. They are represented by crystalline schist of the amphibole, amphibole-biotite-chlorite, and epidote-amphibole content with thickness of more than $2000 \mathrm{~m}$ (Gromov suite). The overlying Inkalin suite, with metaconglomerates at the base, is formed by arkose and quartz-feldspathic metasandstones and metatuffstones, actinolite-epidote-clorite schist, quartz-albite-muscovite-chlorite schist, and quartz-albite-sericitic schist with a thickness of more than $800 \mathrm{~m}$. The Inkalin suite is overlain by metamorphic conglomerates at the base of Naskhok formation. This formation is: composed by phyllites, quartzites, and quartzitic-sandstones with thickness not less than $800 \mathrm{~m}$. Upper Silurian-Lower Devonian deposits form the Dremkhed suite, which is exposed in the N.W. part of the island and in the interfluve of the Neizvestnaya river and river Krasnyi Flag. The suite is formed by argillites, sijtstones, and quartzitic sandstones with numerous faunal remains of brachiopods, ostracods, bryozoans, corals and pelecypods.

Upper Devonian sediments with a thickness of not less unan 150 m are exposed on the southern part of the island at the headwaters of the somnitelnayd and khishniko" 
rivers, and comprise of sandstones, limestones, and shale with interbeds of the gypsum. Lower and Middle Carboniferous deposits are widely distributed on the island, and presented by two different type of sections in northern and southern parts of the isiand. In the southern part of the island Carboniferous deposits transgressively overlap Upper Devonian sediments and contain lenses of conglomerates at the base. The sections here are more completed and presented by Tournaisian, Visean, Serpukhovian, Bashkirian,' and Moscovian stages with total thickness more than $800 \mathrm{~m}$. They are characterized by frequent alternation of the laminated clayey limestones and shale. Organic remains; are poor, and mostly presented by foraminiferas.

On the northern part of the island Carboniferous section is incompleted, where Tournaisian and Visean beds were not found. Serpukhovian sediments with coarse pebble conglomerates at the base transgressively overlap Precambrian and Lower Cambrian deposits. Carboniferous deposits formed mostly by massive organic-bearing limestones with interbeds of the calcareous breccia. The thickness of some limestone's formations is up to $200 \mathrm{~m}$. Total thickness of the Carboniferous deposits of the northern part of the island is about $650 \mathrm{~m}$. Bryozoan-coral bearing bioherms and numerous faunal remains of brachiopods, bryozoans, corals, goniatites, gastropods, crinoids, nautiloids, trilobites, and pelecypods were found and they are very characteristical for northern carboniferous zone.

Upper Permian deposits transgressively overlie different horizons of the Lower and Middle Carboniferous sediments. They were found for the first time during the field work in 1972, and their limited distribution can be, perhaps, explained by insufficient survey and/or by lithological similarity with underlying deposits. The Upper Permian deposits were found on the northern part of the island: at the lower course of the Neizvestnaya river, on Kit and Tundrovaya mountains, and in the southern part of the island - at Nasha mountain and at Mamontovaya river. They consist of argellites and organic -bearing limestones with thickness about $150 \mathrm{~m}$. Limestones contain numerous remains of pelecypods of Kolymia genera and foraminifers, what permited to date this horizon as Dzhigdalin*.

Upper Triassic deposits were found in the southern part of the island, where they transgressively overlie older formations of different ages. They are represented by interbeds of sandstones, siltstones and arrillites with total thickness of 1000-1500 $\mathrm{m}$. 
Friable Quaternary deposits are widely distributed along all island. In the area of mountains they are represented by a colluvial blanket. The southem coastal plain and tundra of Akademii are covered by lacustrian-alluvial sediments.

The igneous rock series is known only in Proterozoic metamorphic complex. It is presented by sublatitudinal, concordant to the main structural elements of the metamorphic complex, beds which formed by gabbro-diabase, diabase, leucocratic granite porphyry, and porphyritic granite.

All deposits of Vrangel island are dislocated in different styles. The most complicated structures are of Proterozoic and Lower Cambrian ages in the central part of the island which are isoclinally folded. Palaeozoic deposits in the southern part of the island are plicated in the system of linear folds overturned to the north. This folding is intermediate*, very close to holomorphic** type, but contain some elements of block folding.

The structures of the northern part of the island are less complicated. Palaeozoic deposits were plicated in a series of brachysynclines separated by crest lines. The folding, as in the southern zone, is of intermediate type, but close to idiomorphic* type. In the central part of the island

* Intermediate folding - combines properties of the holomorphic and idiomorphic foldings. It is characteristic of some foredeeps, platform margins, and final stage of geosynclinal cycle.

* Holomorphic type of folding - developes in fold zones and is characterized by: 1) continuity of its development along all fold zone 2) equal development of anticlines and synclines 3) linearity 4) preferred direction of mass movement, what reflects in equal dip of the axial surfaces along all fold zone. Syn.: linear folding 
there is block folding.

The stratigraphy and mineralogy of the island, analyses of thicknesses of formations, sedimentalogical breaks, unconformities, and dislocations permitted to distinguish three structural-facies complexes.

The oldest one is a Late Proterozoic-Early Cambrian complex, which can be characterized by regional metamorphism of the lowest level of amphibolite facies, presence in the sections of the extrusive and intrusive formations, holomorphic type of folding, and thickness of about $4000 \mathrm{~m}$. This evedence suggests, that the Late Proterozoic-Early Cambrian facies complex was formed in geosynclinal conditions of the Baikalian tectonic cycle. The noses of the Baikalian folded basement were, perhaps, major sourses of the erosional debris, that is reflected by the presence of the metamorphic boulders in Inklipalaeozoic conglomerates. The conglomerates contain, also, some pebbles of surite? gneissose granite, which were not found in the basement. This fact could be Noshotinterpreted as that the basement contains also some older metamorphic rocks. or Eciorbon ? The overlying Middle-Late Palaeozoic complex was formed after a long break during Early Cambrian-Late Silurian. From Late Silurian up to Late Permian all area was under platformal conditions. The deposits of Vrangel island during that period can be characterized by: small thickness ( 1100 - $1200 \mathrm{~m})$, predominance in the sections of limestone and dolomite, presence of the quartzitic sandstones, absence of the igneous formations, and idiomorphic type of folding***.

** Idiomorphic type of folding - it is a plains-type folding which characterized by: I) intermittence and localization inside of horizontal beds area

2) irregular development of the anticlines and synclines 3) non-linearity 4) lack of preferred direction of mass movement. Term was given to platform structures.

Example: Black Hills. Syn.: Intermittented folding of platform structures. 
The following Iate Triassic deposits were formed, probably, in geosyncline conditions. In comparison to Late Silurian-Late Permian period, the thickness of sandy-shale formation increased drastically, and can be discribed as. flyshoid. The thickness of the Late Triassic terrigenous deposits is about the same as of the all Palaeozoic, and is more than $1500 \mathrm{~m}$. The formations of Vrangel island took part in very intensive Mesozoic tectogenesis inside of the Verkhoyano-Chukchi geosyncline area.

The geological hystory of the Vrangel island shows similar tectonical conditions of the Novosibirian islands, of the Eastern part of the Chukchi peninsula, and of the N.W. part of Alaska.

The geosynclinal conditions of the Novosibirian islands during the Baikalian tectonic cycle were confirmed by recent investigations undertaken by NIIGA. According to data obtained by Volnov D.A.(1975), during Middle- Late Proterozoic the area of the Novosibirian islands and most of the East Sibirian sea were formed in geosyncline conditions. In the north-western part of Alaska, on the Stuart peninsula, the Late Proterozoic deposits are represented by "Noum group" which can be correlated with Gromov suite of the Vrangel island, and"shales of the York area" are lithologically similar to Inkalin suite and Naskhok formation.

In the eastern part of the Chukchi peninsula, volcanogenic-terrigenous rocks with thickness up to 4000-5000 m were metamorphosed up to amphibolite facies.

During the Palaeozoic, the major part of the north-eastern sector of the Arctic had sedimentary environment close to platform conditions.

Middle Palaeozoic deposits of the Vrangel island are represented by terrigenous Dremkhed suite of the Late Silurian-Early Devonian age with thickness of $400 \mathrm{~m}$. Similar deposits of the Novosibirian islands are limestones and dolomites with faunal remains, and thickness is about $1700 \mathrm{~m}$. In the 
Chukchi peninsula Upper Silurian deposits are absent, but Lower Devonian deposits were formed by sandstones and siltstones with dolomitic interbeds, and transgressively overlay Lower Silurian and older formations. The Lower Devonian series is represented by two suites: Enmakay suite with a thickness of $270 \mathrm{~m}$, and Pilkhikay suite with thickness of $430 \mathrm{~m}$. In the meantime, the Upper Silurian-Lower Devonian deposits of the N.W. part of Alaska are formed by quartzites and shale with total thickness of about $1000 \mathrm{~m}$.

Middle Devonian deposits are not represented on the Vrangel island, but on the Novosibirian islands they are characterized by limestones and dolomites with faunal remains and thickness of about $1000 \mathrm{~m}$. In the Chukchi peninsula Middle Devonian deposits form the Long suite and are represented by sandstones and siltstones with few interbeds of the limestones, with total thickness of $550 \mathrm{~m}$. In the N.W. part of Alaska, Middle-Upper Devonian deposits are not separated, and formed by terrigenous-carbonaceous deposits with thickness of $1500 \mathrm{~m}$.

Upper Devonian deposits of the Vrangel island have thickness about $150 \mathrm{~m}$ and formed by sandstones, limestones, shale, and gypsum. In Kotelniy island the thickness of the Upper Devonian deposits decreases from $7300 \mathrm{~m}$ of terrigenous deposits on the westem part of the island to a few hundred meters of limestones and dolomites on the eastern part. Upper Devonian deposits of the Chukchi peninsula are represented by sandstones and siltstones of the Pegtymelskaya suite with a thickness of $360-400 \mathrm{~m}$.

Thus, the Late Silurian-Devonian deposits of the Kotelniy island, Chukchi peninsula, and of the N.W. part of Alaska are uninterupted and show more complete sections than of the Vrangel island. These deposits have a thickness of $10.000 \mathrm{~m}$ on the western part of the Kotelniy island and of $3.000 \mathrm{~m}$ on the eastern part. On the Chukchi peninsula the total thickness of the late Silurian-Devonian deposits is about $1700 \mathrm{~m}$, and the thickness of these deposits 
in N.W. part of Alaska is more than $2.500 \mathrm{~m}$. But the thickness of the Late Silurian-Devonian deposits of the Vrangel island is $650 \mathrm{~m}$ only.

Carboniferous and Permian formations of Vrangel island, Novosibirian islands, Chukchi peninsula, and N.W. part of Alaska do not have so many differences as Middle Palaeozoic deposits.

Carboniferous deposits of the Kotelniy island are represented in two different structural-facies zones: 1 . western zone with thick (up to $1.700 \mathrm{~m}$ ) Lower and Middle Carboniferous deposits, and 2. central and eastern part of the island with thin ( up to $20 \mathrm{~m}$ ) Middle and Upper Carboniferous deposits. Lower Carboniferous deposits conformably overlie Upper Devonian through a transitional zone. They formed by sandstones, siltstones, argillites, and interbeds of limestones with a total thickness of $1.500 \mathrm{~m}$, and contain faunal remains of the foraminiferas and brachiopods. Middle Carboniferous deposits of the Western structural-facies zone are represented only by the Bashkirian stage. They are mainly formed by argillites, siltstones, and sandstones with some interbeds of foraminifera-bearing limestones. Thickness of the Bashkirial stage deposits is $175 \mathrm{~m}$. Non-segmented Middle-Upper Carboniferous deposits ar! formed by brachiopoda- and foraminifera-bearing conglomerates and limestones with thickness of $20 \mathrm{~m}$. Lower Permian deposits are formed mainly by argillite: and siltstones with rare lenses of limestones. The thickness of the Permian deposits is not more than $100 \mathrm{~m}$. Upper Permian deposits are represented mostly by argillites with interbeds of the siltstones and fine-grained sandstones in the upper parts of the sections. The thickness of the Upper Permian deposits is about $100 \mathrm{~m}$.

The earliest Carboniferous deposits of the Chukchi peninsula are dated as of the Visean stage, or, in some sections as Middle Carboniferous. They transgressively overlay Devonian or older deposits. Visean, Namurian, and Bashkirian stages are represented by the Yunon suite, which formed mainly by 
limestones with a thickness of $250 \mathrm{~m}$, and sandstones and conglomerates at the base of the suite with a thickness of $50 \mathrm{~m}$. The Kiber suite conformably overlies the Yunon suite, and is formed by sandstones and siltstones with a thickness of about $500 \mathrm{~m}$. It has been dated as of the Moscovian stage.

Continental deposits of the Etakun suite with thickness of $600 \mathrm{~m}$, and of the Iultin suite with a thickness of $1.100 \mathrm{~m}$ were conventionally related to Upper Carboniferous and Lower Permian series respectively. They are formed by sandy shale, clay shale, and coaly-clay shale with some flora remains.

The lowermost Carboniferous deposits of the N.W. part of Alaska are represented by the Kayak formation with thickness of about $200 \mathrm{~m}$, which unconformably overlies Upper Devonian. Kayak formaition composed of argillites, sandstones, and conglomerates at the base. The thickness of the superposed deposits of the Lisburne group varies from $650 \mathrm{~m}$ on the N.W. part of Alaska to $1.500 \mathrm{~m}$ on the N.E. part, and formed mostly by limestones and dolomites with flinty inclusions and some interbeds of clay shale. Faunal remains of brachiopods, corals, and foraminifers permited dating of the Lisburne group as Early and Middle Carboniferous. Armstrong A.K.(1970) and Brozge W.P.(1962) noticed that the Lisburne group is characterized by the following age migratio : on the south, at the central part of the Brooks Range, it represented by Lower and Upper Mississippian, but farther to the north, the Lisburne group is characterized by Upper Mississippian or Middle Pennsylvanian stages. The same characteristics of the Lisburme group were described by Campbell R.H. (1967) for Lisbume Peninsula at the western end of the Brooks Range: in the southern sections the lowest deposits were dated as Early Mississippian, but in the northern sections - they are Late Mississippian. The similar differences were found in the northern and southern parts of the Vrangel island.

Upper Carboniferous and Lower Permian formations are absent in the N.i. part of Alaska. Upper Permian deposits of Alaska are represented by Saderochi formation in the N.W. part, and Siksikpuk formation in the N.E. part. The 
Sadlerochit formation is the main petroliferous formation of the Prudhoe Bay oil field, and it is composed of argillites and sandstones with conglomerates at the base. The thickness of formation is from 120 to $280 \mathrm{~m}$. The Sadlerochit formation is overlain by thin(only $30 \mathrm{~m}$ of thickness), also petroliferous, Shublik formation of the Triassic age which is formed by limestones, sandstones, and shale.

Thus, the review of the Palaeozoic deposits in the Arctic draw the following conclusions:

- There is significant decreasing of the thickness of the Middle-Upper Palaeozoic deposits from the south to the northward direction, and from the west to the east. For example: the thickness of the Middle-Upper Palaeozoic deposit of the Chukchi peninsula is $3.500 \mathrm{~m}$, in Alaska $-3.600 \mathrm{~m}$, in the western part of the Kotelniy island $-12.000 \mathrm{~m}$, and in the eastem part of the same island - $5.000 \mathrm{~m}$. The thickness of the Middle-Upper Palaeozoic deposits of the Vrangel island is $1.400 \mathrm{~m}$ only.

- The number of sedimentalogical breaks and their duration have the same areal distribution as it was meantioned above. In the Vrangel island sedimentalogical breaks were: Middle Devonian, Upper Carboniferous, Lower Permian, and upper part of Upper Permian (Omolon, Gizhigin, and Khivach horizons). There is also break between the Upper Devonian and Toumaisian stage. In the Chukchi peninsula the only known break is between the Pegtymel (Upper Devonian) and Yunon (Lower Carboniferous) suites. The same sedimentalogical break was found in N.W. part of Alaska in addition to Upper Carboniferous and Lower Permian breaks. In the Kotelniy island the break is between Middle and Upper Carboniferous series.

Such sedimentalogical characteristics of deposits suggested the existance of a platform in the northern part of the Arctic during Middle-Upper Palaeozoic. The concept of the existance of the Hyperborean platform in the Arctic 
was drawn for a long time and has been reflected in some tectonic maps, but there are still very few real geological facts in support of that. The existance of the Hyperborean platform during the Upper Palaeozoic was demonstrated by Ustritskiy V.I. (1975). Volnov D.A. (1975) suggested that the area of the Novosibirian islands was under platform conditions beginning from Lower Palaeozoic time. The platform conditions on Vrangel island were established, probably, from the Middle Cambrian period ( Kameneva G.I., 1975 ). The southern boundry of the Hyperborean platform on Vrangel island could be, probably, the major thrust belt which was found and mapped along the southern slopes of the Central mountains.

Also, according to the last data of US geologists and geophysicists, the thrust zone has been determined in the N.W. part of Alaska. Water-borme seismic survey and hydromagnetic prospecting of the Chukchi sea permited tracing of the thrust zone from the northem cape of the Lisburne peninsula at $300 \mathrm{~km}$ distance up to Gerald Bank and farther to the Gerald island and Vrangel island. On the shelf, according to geophysical data, the thrust zone is the boundry between Cretaceous and Cenozoic deposits to the north, and Pre-Mesozoic to the south.

As it was said, the Upper Palaeozoic sections of Vrangel island and N.W. part of Alaska are very similar. These similarities are in mineral composition age of the sediments and of the sedimentalogical breaks, and thicknesses of the Upper Palaeozoic deposits. As in the Vrangel island, the dislocations in the N.W.part of Alaska are less intense in a northem direction.

The geological similarity of Vrangel island and the N.W. part of Alaska also can be drawn from the mineral composition of pebbles in terrigenous Palaeozoic formations. The studies of the conglomeratic pebbles at the base of Upper Silurian-Lower Devonian, Upper Devonian, Lower Carboniferous, and Upper Permian formations show that they contain metamorphic rocks, granites, 
and gneissose granites. The Palaeozoic conglomeratic pebbles of Alaska have similar content. It shows, that during Palaeozoic time the Vrangel island and Alaska have the same provenance. 
BITUMINOLOGICHESKAYA KHARARTERISTIKA RAMENNOUGOL' NYKH I TRIASOVYKH OTLOZHENIY OSTROVA VRANGELYA

B. A. Klubov

Severo-Vostochnyy kompleksnyy nauchno-issledovatel'skiy institut

BITUMINOLOGICAL CHARACTERISTICS OF THE CARBONIFEROUS AND TRIASSIC DEPOSITS OF WRANGEL ISLAND

B. A. Klubov

Northeastern Multidisciplinary Scientific Research Institute 


\title{
BITUMINOLOGICAL CHARACTERISTICS OF THE CARBONIFEROUS AND TRIASSIC DEPOSITS OF WRANGEL ISLAND
}

\author{
B. A. Klubov
}

The importance of the Arctic islands as bases for oil and gas exploration has increased noticeably in recent years. Wrangel Island, situated on the shallow shelf of the East Siberian and Chukchi seas, is of great interest in this respect. Special research, best exemplified by a lithological and bituminological study of the sedimentary layer making up the structure of Wrangel Island, has been begun for the purpose of providing a prognostic assessment of the prospective oil- and gas-bearing capability of this island and the bodies of water adjoining it. Carboniferous and Triassic deposits have become the primary subject of this study.

Carboniferous rocks are quite widely distributed on Wrangel Island. The layer of Carboniferous deposits occupying Wrangel Island's eastern shore consists of three lithologically diverse strata: the lower stratum - a carbonaceous-terrigenous layer with a thickness of $130-150 \mathrm{~m}$; the middle stratum - an essentially carbonaceous layer with a thickness of 400-450 $\mathrm{m}$, and; the upper stratum - a primarily terrigenous layer with a thickness of 900-1,000 m. The lower stratum, located to the south of Dublitskiy Bay, has been described and is comparable to the upper portions of the Berry suite, which are tentatively relegated to the Late Devonian period of the Early Carboniferous age. This stratal layer is represented by alternating bands and members composed of the conglobreccia of conglomerates, marbelized limestones, clay shales, and clay-chlorite shales. The clay and clay-chlorite shales are the best developed components in this stratum, comprising members 
with a thickness of up to $30 \mathrm{~m}$. The middle stratum (or the Waring* suite) is represented by alternating members of brecciated, dolomitized, and sandy limestones, organogenic limestones, and gigantobreccia consisting of large blocks (as big as 1-1.5 m in girth) of limestone and dolomite. The thicknesses of the individual members in this stratal layer range from 30 to $50 \mathrm{~m}$. The coral and brachiopod fragments detected in this stratum place it in the Early Carboniferous age (the Viséan and Namurian periods). In the eastern portion of the island, upper-stratum Early Carboniferous terrigenous deposits, known as the Pillar suite, occupy (and also often overlap) the different levels of the Waring suite with angular variance. The Pillar suite is predominantly composed of clay shales and schistose siltstones, forming flyschoid series with a thickness of 50 to $130 \mathrm{~m}$.

On the western shore of Wrangel Island, the Carboniferous layer starts with thick (as deep as 50-60 m) interstratified members of calcareous clay-mica. sandstones, clay shales, and clay-chlorite shales, directly above which a member (roughly $100 \mathrm{~m}$ thick) of Viséan-Namurian organogenic limestones rests. Here, the upper portion of the Early Carboniferous 1ayer (195-200 m thick) is primarily made up of carbonate-bearing clay shales and schistose clay limestones. This Early Carboniferous layer ends with a bed ( $6 \mathrm{~m}$ thick) of organogenic limestones, over which Late Triassic clay shales are distributed with angular variance.

Triassic deposits are also quite widespread on Wrangel Island. In most instances, these deposits overlap or overlie the different Paleozoic levels with angular and azimuthal variance. According to observations made by the author, the Triassic layer of Wrangel Island consists of three strata:

*Translator's Note: An exhaustive search of personal and three library reference stacks failed to provide a confirmed transliteration for the proper name "Uering", as spelled in the Russian. The most common rendering, "Waring", is used throughout this text, although "Wareing", "Wehring", and "Wering" also constitute viable alternatives. 
the lower stratum, which is essentially argillaceous; the middle stratum, which is apparently transitional, being represented by clay shales, siltstones, and sandstones, and; the upper stratum, which is primarily composed of sandstones. Some $500 \mathrm{~m}$ of the lower stratal layer consists almost entirely of black clay shales. Individual bands and members of fine-grained micaquartz and quartz-feldspar sandstones occupy the upper 300-meter portion of the lower stratum. The maximum thickness of this stratum (in the western section of the island) is $700-800 \mathrm{~m}$. The middle stratum is characterized by a preponderance of micaceous siltstone members (as much as $35 \mathrm{~m}$ thick). Clay shales are not characteristic of this stratum, although individual bands thereof are encountered infrequently. The thickness of the middle stratum is 280-300 $\mathrm{m}$. The upper Triassic stratum is chiefly represented by sandstone members (20-25 $\mathrm{m}$ thick) with a mica-feldspar-quartz composition. In turn, these sandstone members are separated by beds (as much as $20 \mathrm{~m}$ thick) of finely interstratified siltstones, siltstone shales, and clay shales. The thickness of the subject sandstone members increases toward the upper portion of the stratum, as does their role in the layer as a whole. The apparent thickness of this stratum is $330-350 \mathrm{~m}$, but is quite probably somewhat greater. The overall thickness of the Triassic layer appears to be no less than $1,300-1,450 \mathrm{~m}$. The presence of a pelecypod assemblage places the age of Wrangel Island's Triassic deposits in the Late Triassic period (the Carnian and Norian stages).

The luminescent bituminological method (some 250 specimens) and a procedure involving hot extraction in a Soxhlet apparatus (50 large specimens) were employed over the course of this bituminological study of Wrangel Island's Carboniferous and Triassict deposits. The content of organic carbon

*A11 analytical work was carried out by a team of analysts under the supervision of Ye. P. Balykina. 
$\left(c_{o r g}\right)$ in the rocks examined was concurrently determined using these same two types of analyses.

Based on data obtained from luminescent bituminological analysis, it was found that the content of chloroform bitumoid (the MBA type) in sandstones and gritstones from Wrangel Island's lower Carboniferous stratum averages $0.0012-0.0018 \%$

The content of this same bitumoid in similar upper-stratum rocks does not exceed $0.0003 \%$ on the average. Despite the extremely small volume of bitumoid A detected in Triassic sandstones, an average increase of 0.0004 to $0.004 \%$ in the content of this bitumoid is clearly observed as one progresses up the layer, while the content of bitumoid A in siltstones drops slightly. The content of bitumoid A in siltstones from Carboniferous deposits does not exceed $0.0005 \%$ on the average. In siltstones from the lower and middle Triassic strata, the content of bitumoid A comes to no more than 0.0009-0.0021\%, with the average content of bitumoid A reaching $0.002 \%$ in upper-stratum siltstones alone.

A low content of this component is also noted in carbonate-bearing rocks from the Carboniferous period. In this instance, the average content of bitumoid A (MBA) in lower-stratum carbonates came to $0.003 \%$, while the middle and upper strata contained $0.0006 \%$ each. Such a low bitumoid A content (below the Clark value) is apparently due to a high degree of metamorphism on the part of surrounding deposits, which reached the phyllite and phyllitized shale stages during Wrangel Island's Triassic period (just as on the Chukot Peninsula). Under such conditions, only an extremely small amount of bitumoids - clearly a residual volume - could have been stored in the rocks. It is known, for example, that metamorphism generally reduces the bitumoid content of rocks by three times or more (V. A. Uspenskiy, A. S. Chernysheva, et a1., 1949). 
In the majority of cases, the results obtained from hot extraction also confirm this hypothesis concerning the residual nature of the aforementioned bitumoids. The content of bitumoid A in Carboniferous and Triassic clay shales is, as a rule, less than $0.01 \%$. In all specimens, any elevation of the bitumoid yield is directly dependent upon an increase in the $\mathrm{C}_{\mathrm{org}}$ content of the rocks. At the same time, the degree of bituminosity of organic matter (OM) is altered in inverse proportion. Moreover, while no clear-cut regularities exist for Carboniferous specimens, the content of bitumoid A gradually increases in Triassic clay shales as one moves up the layer, rising from $0.005 \%$ in the lower stratum to $0.015 \%$ in the upper stratum, during which $\mathrm{C}_{\text {org }}$ content changes in the same direction, rising from $0.5-0.7 \%$ to $2.55 \%$.

A slightly elevated bituminosity is characteristic of carbonate rocks from Carboniferous deposits (with the content of bitumoid A rising from $0.004 \%$ to $0.013 \%$ ), as is a quite considerable degree of bituminosity for the OMs contained therein ( $B$ coefficient of up to 57.0). In this instance, organogenic limestones from the lower and middle Carboniferous strata possess the highest degree of bituminosity, such specimens being distinguished by a dark color (ranging to black) and an oily odor. (upon impact). Within carbonate rocks themselves, bituminosity drops insignificantly as one progresses up the layer (in an opposite direction, for example, to that observed in Triassic clay shales), falling from $0.013 \%$ in the 10 wer stratum to $0.004 \%$ in the upper stratum.

Although it did not yield unequivocal results, an analysis of the elemental and constituent compositions of bitumoids nonetheless demonstrated the following. Chloroform bitumoids containing a small amount of carbon (66-78\%) and a high volume of heteroelements (as much as $24-26 \%$ ) are present in the majority of both Carboniferous and Triassic clay shale specimens. 
A low oil content (averaging $30-50 \%$ ) is characteristic of the majority of these acidic bitumoids. At the same time, alcohol-benzene resins (with a volume as high as $60.5 \%$ ) constitute the main component of bitumoids. A - low carbon content is primarily noted in the bitumoids of carbonate rocks from Carboniferous deposits (66-72\% on the average). On the other hand, a slightly elevated carbon volume is characteristic of Triassic clay shales (more than $75 \%$ ). Judging from the data contained in extant literature, low carbon volumes of this type are usually encountered in alcohol-benzene extracts. However, an altogether normal chloroform bitumoid, recovered through the use of a prepurified solvent, is referred to in our example. This selfsame alcohol-benzene bitumoid was also recovered from specimens, but only after its chloroform counterpart had been obtained. It is significant that the content of the former in Triassic shales is often 1.5-2 times higher than that of the chloroform extract. In many carbonate rocks from the lowermost strata of the Carboniferous layer, the ratio of chloroform to alcohol-benzene extracts reaches a value of $1: 1$, with a preponderance of the chloroform extract even being possible. This fact, together with the total absence of humic acids in the specimens analyzed, constitutes additional proof of the high degree of OM metamorphism present in rocks from the Carboniferous and Triassic deposits of Wrangel Island. A high degree of chloroform extract sulfuring, which apparently results from the ability of hot chloroform to recover sulfur from sulfide-impregnated rocks, should probably be regarded as the main reason behind the low carbon content of bitumoids. It turned out that the carbonate rocks poorest in carbon are rich in pyrite. It should also be noted that bitumoids undergoing the highest degree of oxidation are brown or light brown in color, having a viscous grease-like consistency, while bitumoids with an elevated carbon content (more than $80 \%$ ) are, as a rule, light yellow and petrolatum-like. 
The presence of similar bitumoids in rocks with this degree of metamorphism apparently results from different causes. A significant volume of allochthonous bitumoids is probably present in the organic matter of Viséan-Namurian carbonate rocks, as suggested by the high degree of OM bituminosity in the majority of Carboniferous limestones (a B coefficient of greater than 20.0) and by instances of clearly secondary bitumoids being found in strata of this type. Such secondary bitumoids are confined to the hydrothermal calcite veins (the thickness of which is seldom greater than $0.1 \mathrm{~m}$ ) that intersect dark organogenic limestone members in different directions. The calcium present in such veins has a nonuniform dark coloration (ranging to black) and smells oily upon impact. Bitumoid $A$ is recovered from several similar calcite specimens in a volume ranging from 0.007 to $0.008 \%$ by means of hot extraction with chloroform. Here, an alcohol-benzene extract is also successively obtained from one specimen in a volume totaling $0.1 \%$ of the overall rock weight. The constituent composition of these bitumoids ( $24-39 \%$ oil, 5-12\% benzene resins, 45-50\% alcohol-benzene resins, and 10-13\% asphaltenes) gives some indication of their oxidized and perhaps residual nature. This is also confirmed by elemental composition: $\mathrm{C}-65-71 \%$; $\mathrm{H}-9-11 \%$, and; $(O+N+S)-18-26 \%$. The bituminosity coefficient ( $B$ ) of bituminous calcite specimens is usually no less than 20 .

The slightly reduced type-A bitumoids present in clay shales (especially those from Triassic deposits) are most likely autochthonous bitumoids or, at best, paraautochthonous. These bitumoids are usually contained in rock in a small volume (0.003-0.005\%) and comprise a small fraction of organic matter.

All remaining bitumoids from the collection investigated (i.e., the majority) should be qualified as residual, having been stored over the course of intense tectonic movements, as well as of the catagenic and meta- 
morphic rock transformations linked to such movements.

Thus, the Carboniferous and Triassic deposits of Wrangel Island constitute strata that produced oil in the past. At the present time, these deposits have almost completely exhausted their oil-producing capabilities, as suggested by both metamorphism and the fact that autochthonous and residual bitumoids are predominant in rocks from the layer investigated (especially those from the Triassic period). The presence of secondary hydrothermal bitumoids and the admixture of allochthonous bitumoids present in organogenic Carboniferous limestones apparently indicates the occurrence of local hydrocarbon shifts in strata of this age, caused by the acceleration of tectonic movements into a period entailing the cessation of folding in the neighboring Chukot geosyncline (at the end of the Early Cretaceous period). Possibly, this is the result of tectonic shifts occurring at a later date, including the Late Quaternary period and the Holocene epoch. 
Izvestiya Akademii Nauk SSSR — Seriya Geologicheskaya

(5) : 104-115. 1973

\section{STRATIGRAFIYA OSTROVA VRANGELYA}

O. N. Ivanov

Severo-Vostochnyy kompleksnyy nauchno-issledovatel'skiy institut, Dal'novostochnyy nauchnyy tsentr, Magadan

News From the Soviet Academy of Sciences - Geological Series (5) : $104-115.1973$

\section{STRATIGRAPHY OF WRANGEL ISLAND}

O. N. Ivanov

Northeastern Multidisciplinary Scientific Research Institute, Far East Science Center, Magadan

Translated by Infoplosion, Inc. 
UDC $551.7(1)(470.1)$

\title{
STRATIGRAPHY OF WRANGEL ISLAND
}

\author{
0. N. Ivanov
}

A study of the geological structure of Wrangel Island is essential to the resolution of the geological problems associated with the eastern sector of the Soviet Arctic. A stratigraphic diagram of Wrangel Island, based on materials put together personally by the author of this article, is presented in the work at hand, with allowance being made for and using, in part, the results contained in the works of L. V. Gromov and M. T. Kiryushina, V. M. Basov, A. A. Gorbunov, M. F. Lobanov, M. Ye. Gorodinskiy, S. M. Til'man, et al., and G. S. Gnibidenko.

A Proterozoic-Sinian (?) metamorphic assemblage, terrigenous-carbonate and carbonate deposits from the Early and Middle Carboniferous period, and essentially terrigenous formations from the Late Triassic period can be distinguished on Wrangel Island.

\section{The Proterozoic-Sinian (?) System (The Wrangel Assemblage)}

The metamorphic rocks of the Wrangel assemblage crop out in the central section of the island, taking the form of a narrow strip (3-9 $\mathrm{km}$ wide) which extends almost $100 \mathrm{~km}$ in a latitudinal direction, from Cape Florens [Florence] in the west to the main course of the Klark [Clark] River in the east. The metamorphites making up the horst occur monoclinally, dipping to the south in a gently sloping manner. The most complete cross-section of the Wrangel assemblage was studied by the author at the headwaters of the Khishchnikov River. Supplementary partial cross-sections 
were traced in the Mamontovyye [Mammoth] Mountains, at the headwaters and in the main course of the Klark River, and in the region of Cape Florens.

A generalized layer-by-layer cross-section of this metamorphic stratum (from the bottom up) is as follows:

1. Clinozoisite-epidote-feldspar and epidote-quartz-chlorite shales with multicolored schistose gritstone lenses are present at the

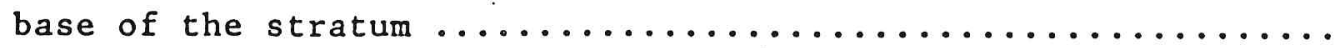

2. Large-augen granite gneisses ..................... 160-200 m

3. Sandwiched grey and violet phyllites, chlorite, mica-chlorite,

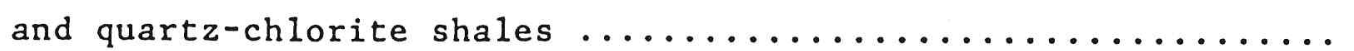

4. Amphibole-chlorite, amphibole-clinozoisite-chlorite, and mica-

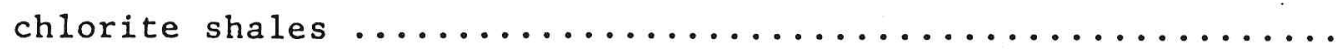

5. Grey, greenish-grey, and cherry-colored phyllites with beds of

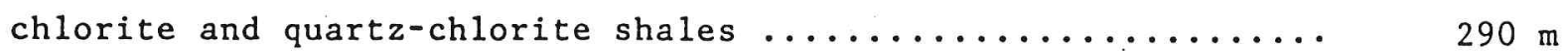

6. A sil1-1ike body of leucocratic granites ................

7. Chlorite-quartz, mica-chlorite, and clinozoisite-quartz-feldspar

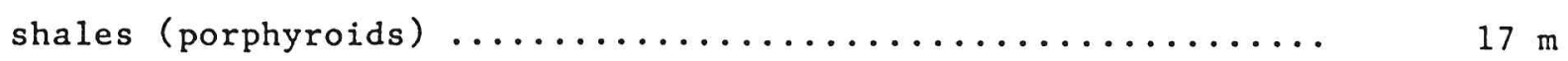

8. An interstratified body of granosyenites .............. $40 \mathrm{~m}$

9. Multicolored schistose gritstones and conglomerates ........ $40 \mathrm{~m}$

10. Chlorite-quartz-feldspar, feldspar-quartz, and clinozoisitequartz-chlorite shales, including a sil1-like body of amphibol-

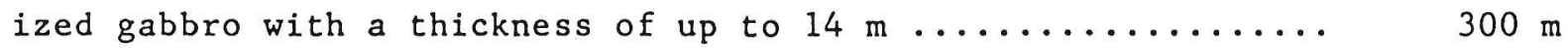

11. Chlorite, mica-chlorite, and chlorite-quartz shales with igneous rock pebble, vein quartz, and quartzite xenoliths ("pudding"

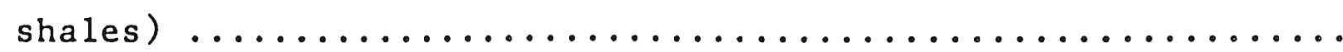

12. Epidote-chlorite and chlorite-quartz-feldspar shales (porphyroids) with gritstone lenses 
13. Chlorite and quartz-chlorite shales $\ldots \ldots \ldots \ldots \ldots \ldots \ldots$

14. Schistose gritstones with chlorite shale and large-pebble con-

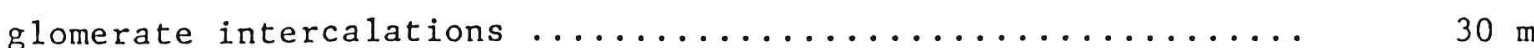

15. Feldspar-mica-chlorite shales (porphyroids) $\ldots \ldots \ldots \ldots \ldots$

16. Schistose conglomerates and multicolored gritstones containing mica shale, vein quartz, igneous rock, and rose-colored, violet, and green microquartzite pebbles $\ldots \ldots \ldots \ldots \ldots \ldots \ldots$

17. Violet and grey phyllites with mica-chlorite shale intercalations, infrequent gritstone lenses, and isolated dark plumcolored limestone intercalations $\ldots \ldots \ldots \ldots \ldots \ldots \ldots \ldots \ldots \ldots \ldots \ldots$

18. Individual long-fibered gypsum lenses $\ldots \ldots \ldots \ldots \ldots \ldots \ldots$

19. Black carbon-like phyllitized clay shales with infrequent thin (up to 0.4 m wide) intercalations of grey and greenish-grey

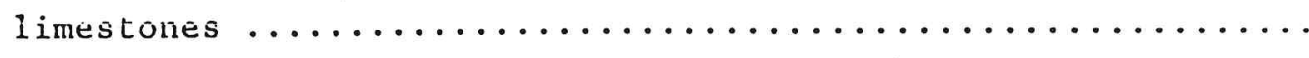

20. Fine-grained dolomites, arenaceous dolomites, and quartzite shales containing lenses, veins, and pockets of hematitic mica

The overall thickness of the visible portion of this cross-section is 2,800 m.

The appurtenance of layers 18-20 to the Proterozoic-Sinian age seems dubious to us. It can not be ruled out that this rock member, having an overall thickness of $390 \mathrm{~m}$, forms part of the base of the Paleozoic crosssection, most probably from the Devonian period.

This stratal cross-section changes rapidly in a horizontal direction (along the strike). In this vein, quartzite shales formed by acid effusives, above which schistose crystal tuffs with gritstone lenses should reside, are encountered in the Mamontovyye Mountains at the level located stratigraph- 
ically over the gneisses instead of the various shales found at the headwaters of the Khishchnikov River. The thickness of this volcanogenic rock bed is $220 \mathrm{~m}$.

The underlying composition of the Wrangel assemblage is volcanogenic and sedimentary. Coarse-grained quartz sandstones with a lesser number of arkose and graywacke varieties clearly dominate this assemblage's crosssection. The rocks in the Wrangel assemblage are metamorphized to the quartzalbite-muscovite-chlorite subfacies stage of the green shale facies.

Stratigraphic contact is not established between these metamorphites and the Early to Middle Carboniferous deposits; the boundary runs along the broken dislocations by means of which the various levels of the ViséanNamurian terrigenous-carbonate deposits make contact with the metamorphic stratum.

The age of the metamorphites emerging in the central section of Wrangel Island has already been a topic of discussion for some thirty years. L. V. Gromov and M. T. Kiryushina, followed by V. M. Basov and A. A. Gorbunov (Lobanov, 1957), relegated this assemblage to the Cambrian-Silurian period. M. Ye. Gorodinskiy (1960) classified it as Proterozoic, while S. M. Til'man, et al. (1964) viewed it within the framework of the Berry suite (Late Devonian to Early Carboniferous). G. S. Gnibidenko (1968) places the age of these metamorphic rocks at no older than the Middle Carboniferous period.

In the author's opinion, Wrangel Island's metamorphic assemblage possesses the following fundamental traits which distinguish it from Paleozoic carbonate formations: (1) the basic composition of the rocks present in this assemblage corresponds to that of a volcanogenic-sedimentary assemblage containing an obvious preponderance of coarse detrital quartz rocks; (2) the rocks in this assemblage are metamorphized to the green shale facies, and; (3) the metamorphic stratum of this assemblage is saturated with intru- 


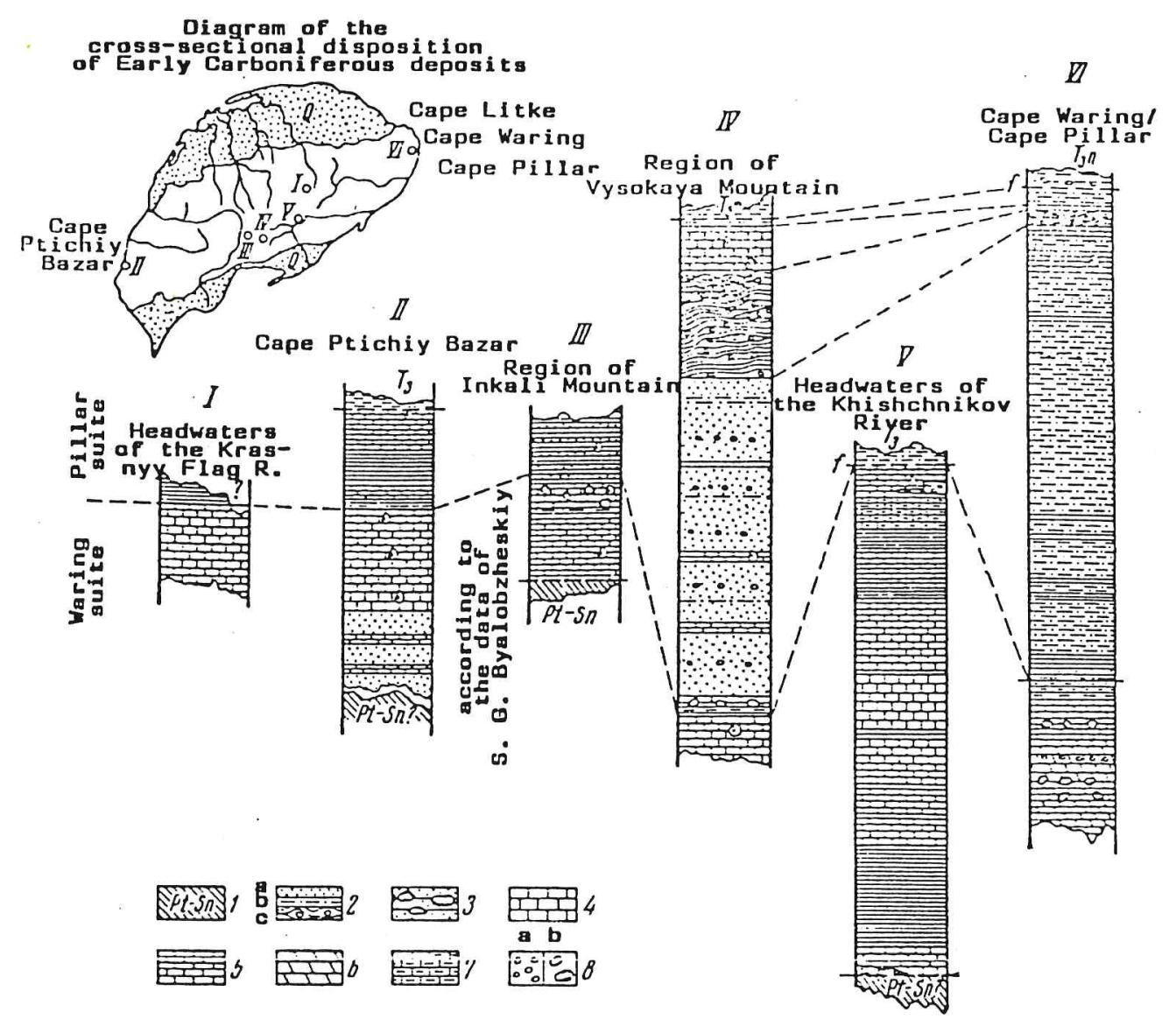
Correlation diagram of the Early Carboniferous cross-sections
of Wrangel Island

1 - Wrangel Island's metamorphic assemblage; 2 - sandstones (a), siltstones (b), and clay shales (c); 3 - conglomerates; 4 - limestones; 5 - thin-bedded limestones; 6 - dolomitized limestones; 7 - siliceous limestones; 8 - concretions (a) and xenoliths (b)

sive bodies of amphibolites, gabbro, granosyenites, and soda granites, all of which are absent in the overlying Paleozoic stratum. We also note that no analogs of the metamorphites described above exist in the known Paleozoic deposits of the Chukot Peninsula, which range from the Ordovician to the Namurian period.

At the same time, a comparison of the Wrangel assemblage to the Proterozoic-Sinian formations of the Northeast demonstrates substantial similarities. The cross-sections of the Avekov uplift (quartzites, phyllites, and marbelized limestones containing Collenia), Ayan Bay (micaceous quartzite 
shales, quartzitic sandstones, sandstones, and phyllites), the Burustasskaya suite of Bol'shoy Lyakhov Island (schistose sandstones and phyllite-like sericite-chlorite-quartz shales)', and the stanovskaya suite of the Chelyuskin Peninsula (conglomerates containing quartz and igneous rock pebbles, quartzites, quartzitic sandstones, phyllites, and chlorite shales) compare well with the metamorphic stratum of Wrangel Island.

The similar geological position and lithological resemblance shared by Wrangel Island's metamorphic assemblage and known Proterozoic-Sinian cross-sections in bordering territories apparently suggest that the metamorphites of Wrangel Island belong to the Sinian-Proterozoic age.

The results obtained from a determination of the absolute age of the magmatic rocks and metamorphites present in the horst of the Tsentral'nyye [Central] Mountains (see the table) demonstrate a large discrepancy and indicate that these rocks underwent multiple transformations, as imprinted in their K/Ar ratio. Here, the fact that muscovitized granites which have been explicitly dated to the rejuvenated ordovician age (525 million years old) break through metamorphites ranging from 513 to 173 million years of age merits attention.

Thus, since potassium-argon dating confirms the Preordovician origin of the metamorphic rocks of the Wrangel assemblage, the parallelization of this time frame to the known Proterozoic-sinian formations of the Soviet . Northeast and its adjacent regions makes it possible to conjecture that the metamorphic rocks of Wrangel Island most probably belong to the Proterozoic-Sinian age.

The lithologically unique stratum that gently slopes through the region of the Drem-Khed [Drum Head] Mountains in a monoclinal manner, which M. Ye. Gorodinskiy (1964) also relegated to the Proterozoic period, constitute a somewhat different situation. According to our materials, dark grey silt- 
Potassium-argon dating of the early metamorphic and igneous rocks of Wrangel Is land

\begin{tabular}{|c|c|c|c|c|c|c|c|}
\hline \multirow{2}{*}{$\begin{array}{l}\text { Sam- } \\
\text { Na. } \\
\text { Na. }\end{array}$} & \multirow{2}{*}{$\begin{array}{c}\text { Spec- } \\
\text { imen } \\
\text { No. }\end{array}$} & \multirow[b]{2}{*}{ Rock and sampling site } & \multicolumn{3}{|c|}{ Content. g/g } & \multirow{2}{*}{$\frac{A_{r^{40}}}{K^{40}}$} & \multirow{2}{*}{$\begin{array}{l}\text { Age. } \\
\text { miliions } \\
\text { pf years }\end{array}$} \\
\hline & & & k & $K^{10}$ & $A_{1}{ }^{10}$ & & \\
\hline 4263 & 159 & $\begin{array}{l}\text { Leucocratic granite. Os'- } \\
\text { minog Mountain }\end{array}$ & 0.0208 & 2.53 & $\begin{array}{l}5.18 \\
5.23\end{array}$ & $\begin{array}{l}0.1905 \\
0.02017\end{array}$ & $\begin{array}{l}321 \\
324\end{array}$ \\
\hline 4270 & 79 & $\begin{array}{l}\text { Leucocratic granite. In- } \\
\text { kali Mountain }\end{array}$ & 0.0108 & 1.32 & $\begin{array}{l}2.21 \\
2.22\end{array}$ & 0.0167 & 265 \\
\hline 4271 & 164 & $\begin{array}{l}\text { Quartz-feldspar shale, head } \\
\text { of the Khishchnikov R. }\end{array}$ & 0.0175 & 2.14 & 3.71 & C. 0173 & 275 \\
\hline 4273 & 98 & $\begin{array}{l}\text { Granodiorite-porphyry peb- } \\
\text { bles. Mamantovyye Mts. }\end{array}$ & 0.0325 & 3.97 & 0.0119 & 0.0110 & 194 \\
\hline 274 & $\begin{array}{l}151 \\
966\end{array}$ & $\begin{array}{l}\text { Felsite. head of Khishch. R } \\
\text { Muscovite-quartz-feldspar }\end{array}$ & $\begin{array}{l}0.0406 \\
0.0138\end{array}$ & $\begin{array}{l}4.96 \\
1.27\end{array}$ & $\begin{array}{l}5.75 \\
4.39\end{array}$ & $\begin{array}{l}0.0116 \\
0.0345\end{array}$ & $\begin{array}{l}187 \\
513\end{array}$ \\
\hline 4276 & $163 d$ & $\begin{array}{l}\text { shale. Mamontovyye Mts. } \\
\text { Large-grained granite peb- } \\
\text { bles. head of Khishch. R. }\end{array}$ & 0.0102 & 1.245 & $\begin{array}{l}4.89 \\
4.90\end{array}$ & $\begin{array}{l}0.0393 \\
0.0394\end{array}$ & $\begin{array}{l}574 \\
575\end{array}$ \\
\hline $2 \pi 7$ & $163 c$ & $\begin{array}{l}\text { Amphibolite. headwaters of } \\
\text { the Khishchnikov River }\end{array}$ & 0.0054 & 0.658 & 0.464 & 0.01705 & 115 \\
\hline 78 & 166 & Augen gneiss. Gronov Mt. & 0.0404 & 4.94 & 5.45 & 0.0110 & 1 \\
\hline & 97 & $\begin{array}{l}\text { Augen gneiss. Mamontovyye } \\
\text { Mountains }\end{array}$ & 0.0 & 4.36 & 6.04 & 0.013 & \\
\hline 1218 & $231-3$ & $\begin{array}{l}\text { Fluidal porphyry. Pervaya } \\
\text { Mountain }\end{array}$ & 0.0335 & 4.33 & 3.49 & $0.008 C 7$ & 133 \\
\hline 1895 & $54 \mathrm{a}$ & $\begin{array}{l}\text { Spherulitic quartz-feldspar } \\
\text { porphyry. Khrustal'nyy } \\
\text { Creek }\end{array}$ & 0.0473 & 5.76 & 4.20 & 0.00729 & 121 \\
\hline 1855 & & $\begin{array}{l}\text { Mica-feldspar shale. efflu- } \\
\text { ents of the Khishch. R. }\end{array}$ & 0.0342 & 4.17 & 4.35 & 0.0104 & 170 \\
\hline 1855 & $423 \mathrm{~b}$ & $\begin{array}{l}\text { Leucocratic granite, head- } \\
\text { waters of Lhe Klurk River }\end{array}$ & 0.0367 & 4.48 & 4.53 & 0.0101 & $165 \pm 3$ \\
\hline 1657 & ¿û̂ิa & $\begin{array}{l}\text { Leucocratic granite-porphy- } \\
\text { ry. head of Khishch. R. }\end{array}$ & 0,0426 & 5.20 & 5.65 & 0.0109 & $178 \pm 5$ \\
\hline 219 & 2553 & $\begin{array}{l}\text { Leucocratic granite. region } \\
\text { at an altitude of } 605.0 \mathrm{~m}\end{array}$ & 0.0349 & 4.26 & 5.63 & 0.0132 & 212 \\
\hline 1858 & 553 & $\begin{array}{l}\text { Granite-porphyry. Khrus- } \\
\text { tal nyy Creek }\end{array}$ & 0.0432 & 5.26 & 6.93 & 0.01315 & $212 \pm 6$ \\
\hline 1851 & $414 \mathrm{~b}$ & $\begin{array}{l}\text { Chlorite-sericite shale. } \\
\text { head of Khishchnikov R. }\end{array}$ & 0.0097 & 1.18 & 2.05 & 0.0174 & $276 \pm 3$ \\
\hline 1852 & $426 a$ & $\begin{array}{l}\text { Unaltered diabase. head of } \\
\text { the Neízvestnays River }\end{array}$ & 0.0096 & 1.17 & 1.915 & 0.0164 & $262 \pm 8$ \\
\hline 1861 & 75 & $\begin{array}{l}\text { Quartzite shale. region of } \\
\text { Cape Floreng }\end{array}$ & $0.0042^{5}$ & 0.52 & 0.865 & 0.0166 & $264 \pm 45$ \\
\hline 220 & $267 a$ & $\begin{array}{l}\text { Granodiorite-porphyry. } \\
\text { Sovetakaya Mountain }\end{array}$ & $\begin{array}{l}0.00425 \\
0.0324\end{array}$ & $\begin{array}{l}0.52 \\
3.95\end{array}$ & $\begin{array}{l}7.08 \\
7.51\end{array}$ & & $\begin{array}{l}269 \\
300\end{array}$ \\
\hline 1853 & 225 & $\begin{array}{l}\text { Muscovite granite. Os'minaq } \\
\text { Mountain }\end{array}$ & 0.0259 & 3.16 & 8.73 & 0.0276 & $421 \pm 6$ \\
\hline 254 & $421 \mathrm{~b}$ & $\begin{array}{l}\text { Muscovite plagiogranite. } \\
\text { effluents of Khishch. } R \text {. }\end{array}$ & $\begin{array}{l}0.0121 \\
0.0121\end{array}$ & $\begin{array}{l}1.48 \\
1.48\end{array}$ & $\begin{array}{l}4.09 \\
3.88\end{array}$ & & $\begin{array}{l}420 \pm 8 \\
402 \pm 8\end{array}$ \\
\hline 186.? & 412 & $\begin{array}{l}\text { Parphyry pebbles from the } \\
\text { conglomerate of Khishch. R. }\end{array}$ & 0.0 & 1. 20 & 3.29 & 74 & $419 \pm 25$ \\
\hline 221 & 512 & Amphibolite. & 0.0124 & 1.51 & 4.56 & 0.0302 & $457 \pm 25$ \\
\hline & & $\begin{array}{l}\text { Arkosic sand } \\
\text { skaya Moun }\end{array}$ & & 2.28 & & & \\
\hline 1863 & $4 C 4 a$ & $\begin{array}{l}\text { Schistase sandstone. Tsen- } \\
\text { tral'nyye Mountains }\end{array}$ & $\begin{array}{l}0.0129 \\
0.0129\end{array}$ & $\begin{array}{l}1.57 \\
1.57\end{array}$ & $\begin{array}{l}2.75 \\
2.95\end{array}$ & & $\begin{array}{l}278 \pm 5 \\
296 \pm 5\end{array}$ \\
\hline 1864 & $53 \mathrm{~b}$ & $\begin{array}{l}\text { Arkasic sandstane. Khrus- } \\
\text { tal nyy Creek }\end{array}$ & 0.0187 & 2.28 & 3.92 & 0.0175 & $273 \pm 7$ \\
\hline 86 & 41 & $\begin{array}{l}\text { Arkosic sandstone. Tsen- } \\
\text { tral'nyye Mountains }\end{array}$ & $\begin{array}{l}0.0257 \\
0.0257\end{array}$ & $\begin{array}{l}3.14 \\
3.14\end{array}$ & $\begin{array}{l}3.32 \\
3.36\end{array}$ & 1055 & $\begin{array}{l}173 \pm 8 \\
175 \pm 8\end{array}$ \\
\hline
\end{tabular}

Annotation: The analysis of samples 4269-4279 was carried out by I. P. Zagruzina (1968) ussing specimens from the author's collection. All remaining analyses were performed by L. V. Firsov (1966) using the following collections: specimens 1218-1221 - M. Ye. Gorodinskiy (1962), and; $1851-1865-$ S. M. Til'man, S. G. Byalobzheskiy, and A. D. Chekhov (1964). The dating constants are $\lambda_{B}=4.68 \cdot 10^{-10}$ and $\lambda_{K}=0.585 \cdot 10^{-10}$ 
stones, black siltstones, and sandy shales containing isolated intercalations of small-grained sandstones occupy the base of this stratum's cross-section. The apparent thickness of this portion of the cross-section is $400 \mathrm{~m}$. Smooth layers of cream-colored and green siltstones with a thickness of $300 \mathrm{~m}$ conformably overlie this cross-sectional layer. Quartzites and quartzitic sandstones - rose-colored and white - are conformably bedded in the lower siltstone member, sometimes being large-grained and possessing an appreciable horizontal schistosity. Intercalations of greenish siltstones are encountered from time to time. The upper beds of quartzitic and quartzite-like rocks, having a thickness of some $200 \mathrm{~m}$, contain gravel, as well as siliceous rock, feldspar, and vein quartz detritus, together with infrequent pebbles and rock wastes of different quartzites (having a diameter of up to $10 \mathrm{~cm}$ ). The thickness of these quartzite members is $900 \mathrm{~m}$. The apparent thickness of the stratum under examination is $1,600 \mathrm{~m}$.

The Drem-Khed stratum described above compares poorly with the Wrangel assemblage. We place this stratum in the Proterozoic-Sinian period, as M. Ye. Gorodinsky tentatively did after us. We feel that the material composition, structure, and degree of metamorphism of the Drem-Khed Mountain assemblage differ substantially from those of the Wrangel assemblage, with the lithology of the former being comparable to the Late Devonian "shale-sandstone" subdivision occupying the eastern portion of Alaska's Brooks Mountains.

\section{The Early Carboniferous Period}

Early Carboniferous deposits are the most widely distributed of all on Wrangel Island. These deposits form expansive fields that extend latitudinally to the north and south of the Tsentral'nyye Mountain horst, crop out in the Gusina River basin and in the region of Cape Ptichiy Bazar 
[Avian Rookery], and make up the coastal cliffs occupying the eastern shore of the island in the region of Cape Litke, Cape Waring*, and Cape Pillar. The subject Early Carboniferous deposits are deformed by a folding that is overturned to the north and is genetically linked to an enormous oveithrust by means of which the Paleozoic and Triassic deposits of the island's southern section, being dislocated in a uniform manner, overlap the horst of the Tsentral'nyye Mountains and the gently sloping limestones that occupy the norther section of the island.

The facially irregular Early Carboniferous stratum can be divided into two suites as a function of lithological properties, these being the lower, or Waring suite, the composition of which is essentially of the carbonate type, and the upper, or Pillar suite, which is predominantly terrigenous in composition. We observed the cross-sections and relationships of these suites among the rocky coastal cliffs of Wrangel Island's eastern shore, from Cape Litke to Cape Utes Bol'shevik [Bolshevik Bluff].

The Waring and Pillar suites both possess durable mapping features and clear-cut lithological boundaries.

\section{The Waring Suite (The Viséan-Namurian Period)}

The reference cross-section of the Waring suite which we selected was studied in the rocky crags of Wrangel Island's eastern shore - from Cape Litke to Lagernyy [Camp] Creek. The rocks of this suite emerge onto the daylight surface along the right bank of the Mamontovaya [Mammoth] River, in its main course, at the headwaters of the Khishchnikov River, and in the upper course of Khrustal'nyy [Crystal] Creek, as well as in the nortern

*Translator's Note: An exhaustive search of personal and three library reference stacks failed to provide a confirmed transliteration for the proper name "Uering", as spelled in the Russian. The most common rendering, "Waring", is used throughout this text, although "Wareing", "Wehring", and "Wering" also constitute viable alternatives. 
section of the island at the headwaters of the Krasnyy Flag [Red Flag], Naskhok, Neizvestnaya [Unknown], and Gusina rivers. Along the unbroken rocky outcrop occupying the region of Cape Waring, this cross-section is as follows (from the bottom up):

1. Rose-colored and greenish strip-layered dolomitized limestones with an apparent thickness of $\ldots \ldots \ldots \ldots \ldots \ldots \ldots \ldots \ldots \ldots \ldots \ldots \ldots$

2. Small-grained grey brecciated limestones containing massive black limestone rock wastes of different sizes .............

3. Small-grained grey limestones containing pelitomorphic limestone

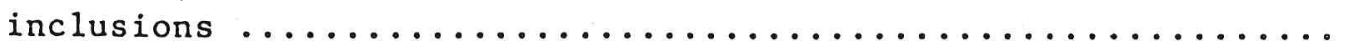

4. Dark grey, almost black, limestones containing large blocks (up to $1.2 \mathrm{~m}$ in diameter) of light-colored and rose-colored dolomitized limestones; conglomerate-like limestones (a layer thickness of $3.8 \mathrm{~m}$ ); higher, alternating whitish "mottled" limestones and variolitic angular inclusions of the dark, predominantly silice-

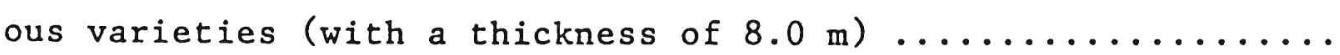

5. Conglomerate-like limestones similar to member 4, but highly brecciated, with the cement of these conglomerates containing recrystallized detrital fragments of sea lily stalks and corals

6. Thin-layered dolomitized limestones $\ldots \ldots \ldots \ldots \ldots \ldots \ldots \ldots$

7. Rose-colored and greenish small-grained dolomitized limestones

8. Rose-colored dolomitized limestones, slightly more large-grained

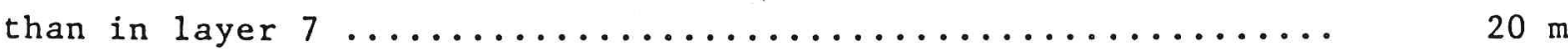

9. Plum-colored thin-layered limestones $\ldots \ldots \ldots \ldots \ldots \ldots \ldots \ldots \ldots . \ldots \ldots$

10. Greenish dolomitized limestones ..................... $9 \mathrm{~m}$

11. Conglomerate-like greenish dolomitized limestones .......... $17 \mathrm{~m}$

12. Conglomerate-like dolomitized limestones containing inclusions 
of the black pelitomorphic varieties $\ldots \ldots \ldots \ldots \ldots \ldots \ldots \ldots$

13. Black pelitomorphic limestones containing recrystallized coral

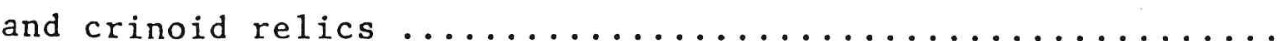

14. Grey platy limestones with isolated inclusions of poorly nodulized light grey limestone lumps .................... 28.0-20.9m

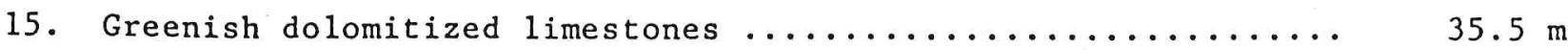

16. Black pelitomorphic limestones containing pearlwort and crinoid

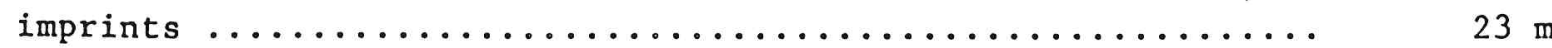

17. Greenish thin-layered and medium-layered limestones ....... $14 \mathrm{~m}$

18. Thinly horizontal-layered greenish and rose-colored dolomitized

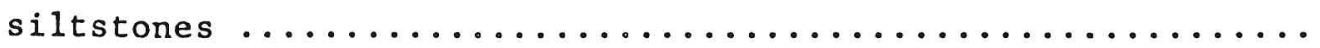

19. Thinly horizontal-layered siliceous limestones, irregularly interstratified with multicolored siltstones; this is the demarcating level of the Waring suite

Conglomerate lenses sporadically distributed throughout the crosssection and containing pebbles with a diameter of 3 to $35 \mathrm{~cm}$ are encountered among the greenish dolomitized limestones of the Mamontovyye Mountains in the Waring suite. The thickness of these lenses is no greater than $1 \mathrm{~m}$, with an expanse of up to $10 \mathrm{~m}$. These pebbles are composed of quartz porphyries, felsites, leucocratic and amphibolic granites with different grain sizes, plagiogranites, multicolored shales, and quartzites.

The overall thickness of the visible portion of the Waring suite's cross-section is $410 \mathrm{~m}$. This cross-section is nonuniform in the horizontal direction. In this vein, the subject suite is represented by limestones of reef origin in the Cape Ptichiy Bazar region, overlapped by calcareous shales. At the headwaters of the Khishchnikov River, this same suite consists of black pelitomorphic limestones which alternate regularly. with clay shales 
and carbonaceous clay shales. The light grey organogenic limestones present along Khrustal'nyy Creek are interstratified with greenish and light-colored argillites.

The relegation of the Waring suite to the Viséan-Namurian period is based on numerous collections of fauna obtained from the limestones present at the headwaters of the Khishchnikov, Krasnyy Flag, and Neizvestnaya rivers, etc. In 1963, S. M. Til'man, S. G. Byalobzheskiy, and A. D. Chekhov collected imprints of Productus (pustula) ex gr. pustulosus Phill., Spirifer ex gr. bisulkatus Sow., and Reticularia sp. from the upper levels of the Waring suite at the headwaters of the Khishchnikov River (these determinations were made by V. N. Krestovnikov and Kh. S. Rozman). In addition, O. M. Lazutkina obtained Fenestella cf. donacia var. major Nikif., F. aff. polyporata Phill., Pimatopora sp. Reteporina sp., Polypora sp., Rombopora sp., Nikiforovella sp., and Sulkoreptopora sp. from this same location.

We collected Echinoconchus punctatus (Mart.), Linoproductus cf. corrugatus (M'Coy), and Camarotoechia pleurodon (Phill.) among the Waring suite limestones present along the right bank of the Mamontovaya River, as well as in its main course. In the opinion of V. M. Zavodovskiy, Spirifer ex. gr. duplicicostus (Phill.), phricodothyris lineata (Mart.), goniatite kernels, coral detritus, and sea lily stalks characterize the upper levels of Viséan and Namurian deposits.

Imprints of Schizophoria resupinata (Mart.), Dictyoclostus ex gr. pinguis M.-W., Antiguatonia ex gr. hindi (M.-W.), Spirifer sp., Fenestella sp., and Crinoidea sp. can be detected in the organogenic limestones present along Khrustal'nyy Creek (these determinations were made by V. M. Zavodovskiy), all of which are characteristic of the Viséan-Namurian period. 
This same individual put together a layer-by-layer cross-section of the suite, pinpointing the structure and composition of its upper levels.

This suite is distributed over the eastern section of Wrangel Island, occupying the Cape Pillar region, the upper course of the Mamontovaya River, and the left bank of Khrustal'nyy Creek's lower course. The Pillar suite primarily consists of siltstones, interstratified with a much lesser volume of sandstones. The cross-section occupying the Cape Pillar region, which was traced by the author, is presented below in a somewhat generalized form:

1. Medium-layered grey and greenish-grey clay shales are conformably bedded at the base of this suite on the siliceous horizontally layered limestones of the Waring suite $\ldots \ldots \ldots \ldots \ldots$

2. Alternating small-grained argillaceous sandstones and siltstones with roughly equal layer thickness ratios $\ldots \ldots \ldots \ldots \ldots \ldots \ldots . . \ldots \ldots$

3. Strip-layered phyllite-like clay shales $\ldots \ldots \ldots \ldots \ldots \ldots \ldots \ldots .28 \mathrm{~m}$

4. Coarsely layered siltstones and argillites containing infrequent intercalations of sandstone, spheroidal pyrites, and calcareous

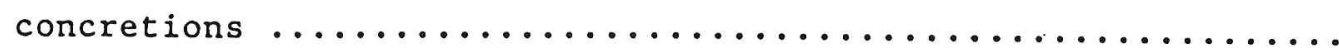

5. Clay shales containing limestone intercalations and organogenic joint sites with a detritus made up of sea lilies, corals, and brachiopods $\ldots \ldots \ldots \ldots \ldots \ldots \ldots \ldots \ldots \ldots \ldots \ldots \ldots \ldots \ldots \ldots \ldots \ldots$

6. Smooth horizontally layered siltstones $\ldots \ldots \ldots \ldots \ldots \ldots \ldots \ldots \ldots .60 . \ldots$

7. Coarsely layered dark grey siltstones $\ldots \ldots \ldots \ldots \ldots \ldots \ldots \ldots \ldots . \ldots \ldots$

8. Medium-layered siliceous siltstones ................ $270 \mathrm{~m}$

9. Black coarsely layered siltstones ........................ $300 \mathrm{~m}$

10. Black crinoidal limestones ...................... $65 \mathrm{~m}$

11. A uniform interstratification of sandstones and thin argillite

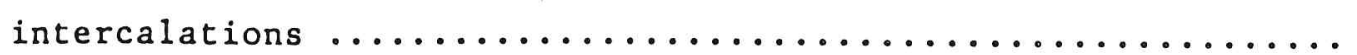




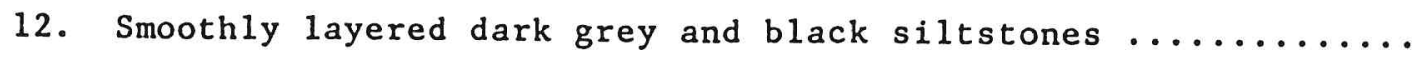

13. Greenish, light violet, rose-colored, and "iridescent" argillites containing limestone detritis inclusions and conglomer-

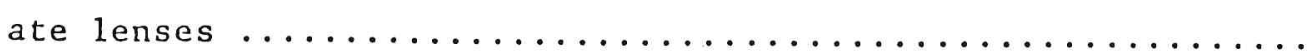

14. Crinoidal and detrital organogenic grey limestones ....... $8.5 \mathrm{~m}$

15. Cream-colored medium-grained limestones $\ldots \ldots \ldots \ldots \ldots \ldots \ldots . .6 \ldots$

16. Black nonlayered siltstones $\ldots \ldots \ldots \ldots \ldots \ldots \ldots \ldots \ldots \ldots \ldots \ldots \ldots \ldots$

A shale stratum from the Late Triassic period overlaps the Early Carboniferous rocks described.

The overall thickness of the portion of the cross-section under examination is $1,400 \mathrm{~m}$.

The composition of the Pillar suite occupying the central and western sections of Wrangel Island differs somewhat from that of the cross-section described above. In the region of Vysokaya [High] Mountain, situated in the central portion of the island, a stratum made up of small- and finegrained sandstone shales, having a thickness of $940 \mathrm{~m}$ and containing infrequent intercalations of clay shales, siltstones, plum-colored limestones, and sometimes crinoidal limestones, rests upon the light-colored limestones of the Waring suite. This arenaceous member is followed by a bed of different greenish phyllitized argillites $300 \mathrm{~m}$ thick which contains lenses and lenslike intercalations of poorly culled conglomerates; as well as the characteristic "floating" vein quartz pebbles and rose-colored or red dolomites. We previously encountered this same bed to the northest of Cape Utes Bol'shevik, although it was not nearly as thick $(40 \mathrm{~m})$. In the Vysokaya Mountain region, directly on the shales described above, rests a 130-meter bed of coral limestones, overlapped by a Late Triassic shale-sandstone stratum.

In the western section of the island and along the left bank of 
the Mamontovaya River's upper course, the Pillar suite is made up of siltstones, carbonaceous clay shales, and sandy shales containing intercalations and individual members of different limestones, occasionally as much as $30 \mathrm{~m}$ thick. Gritstone and small-pebbled conglomerate lenses containing vein quartz gravel and pebbles, small-grained granites, different limestones, and phyllites are encountered in these limestones and, more rarely, in the shale stratum. The relegation of the Pillar suite to the Namurian period is supported, on the one hand, by its conformable overlapping of Waring suite limestones that faunistically characterize the Visean-Namurian period and, on the other hand, by the presence of coral limestones containing ViséanNamurian Botrophyllum magnificium Gorsky, Corwenia toulai var. densa Gorsky, Dibunophyllum turbinatum $\mathrm{M}^{\prime} \mathrm{Coy}$, and Staurophyllum ambigua Gorsky in the upper levels of the Pillar suite occupying the Vysokaya Mountain region (these determinations were made by $\mathrm{Yu}$. I. Onopriyenko of the Northeastern Territorial State University). Since the age of the Waring suite is placed in the Late Viséan and Namurian periods, the Pillar suite, which overlies the Waring suite, naturally must have been formed in at least the Namurian period. The age, however, of the corals collected in the upper levels of the Pillar suite exhibits a considerable vertical range of distribution, which does not make it possible to pinpoint the age of this suite any more closely than the Viséan-Namurian period.

Despite a common facial variability, certain general regularities reflecting the disposition of facies nevertheless exists within each of these suites. Facies of reef origin, which are higher stratigraphically, dominate the lower portion of the Waring suite cross-section occupying the western and northern sections of Wrangel Island. These facies are replaced by terrigenous-carbonate deposits in the southern section of the island and by dolomitized limestones containing vestiges of repeated washouts in 


\begin{abstract}
its southeastern section. The essentially carbonate facies of the Waring suite's Early Carboniferous deposits are vertically replaced by terrigenous Pillar suite formations. As concerns tectonic position and time of formation (the Viséan-Namurian period), facies, and the vertical zonality of facies; the Early Carboniferous deposits of Wrangel Island compare favorably with the Early Carboniferous deposits occupying the extreme eastern portion of the Chukot Peninsula.
\end{abstract}

\title{
The Middle Carboniferous Period
}

In tracing the Early Permian deposits occupying the headwaters of the Krasnyy Flag and Neizvestnaya rivers, as well as the Permian-Carboniferous and Early Permian deposits along Khrustal'nyy Creek, A. A. Gorbunov made reference to Paleozoic rocks younger than Viséan-Namurian formations (Lobanov, 1957). L. V. Gromov discovered Permian-Carboniferous limestones on Cape Ptichiy Bazar.

However, numerous later and more complete fossil remnant collections obtained from these sites suggest that the surrounding strata fall into the Viséan-Namurian period. The marbelized limestones discovered by $G$. S. Gnibidenko (1968) in the Sovetskaya [Soviet] Mountain region, which contain imprints of Choristites cf. barenzi Einor, Choristites sp., Phricodothyris (or Athyris), brachiopod detritus, and sea lily stalks, apparently belong to the Middle Carboniferous period, making it possible, in the opinion of the individual who made these determinations, Ye. A. Ivanova, to date the subject limestones to the Bashkir stage.

G. S. Gnibidenko feels that these Middle Carboniferous limestones form intercalations in metamorphic rocks; however, the position of the metamorphites contained in the Wrangel assemblage at the base of a cross-section known faunistically to be Paleozoic, the mylonitized and broken boundaries 
of the extant limestone lens, and the tectonic "windows" of Carboniferous rocks observed from under an overlapped sliver of early formations confirm the tectonic nature of this limestone lens.

The Middle Carboniferous deposits that we discovered on the castern shore of Wrangel Island come together to form a gently sloping syncline with an amplitude of some $400 \mathrm{~m}$, bound on either side by broken dislocations. This fold is primarily made up of greenish calcareous siltstones, interspersed with black pyritized clay shales, siltstones, and relatively infrequent layers of greenish small-grained micaceous sandstones. Stenoprononites sp. and Diaboloceras ex gr. varicostatum Miller et Furnish goniatites (?) with the characteristic ornamentation typical of the Diaboloceras genus of the Early Pennsylvanian period (the Atok formation), which corresponds to the uppermost levels of the Bashkir stage and the lower levels of the Muscovian stage, were collected from these siltstones and clay shales (these determinations were made by Yu. N. Popov). Numerous Posidonia cf. vaughani Girty and P. cf. wapanuckensis Grity specimens, which are encountered in the upper portions of Early Carboniferous deposits (the Pottsville formation) in the states of Oklahoma and Ohio, were collected from the goniatite-bearing layers. Shells of the Edmondia genus, detected in this same location, are apparently related to a new species. In the opinion of the individual making these determinations, V. A. Muromtseva, the forms mentions are also characteristic, with a certain degree of conditionality, of the Middle Carboniferous period, probably its lower section.

Aside from tectonic contacts, we anticipate the possibility of normal stratigraphic relationships in the lower and middle divisions of Wrangel Island's Carboniferous deposits. This assumption is based on the lithological similarity existing between these deposits and the upper levels of the Pillar suite. These and other suites are comparable with respect to the carbonaceous 
nature of their cross-sections and the place of the eastern Chukot Peninsula's structural-facial zone in the general evolution of the Late Paleozoic period (an upward increase in the role of the terrigenous material present, starting as early as the Namurian period).

In addition to the Middle Carboniferous deposits that occupy the Late Paleozoic cross-section of Wrangel Island, formations from the Late Carboniferous period are also apparently present, as suggested by the collections that M. Ye. Gorodinskiy obtained to the southeast of Cape Pillar, where he detected, in the crinoidal limestones present there, Caninella aff. murchisoni Fomitchev and Donophyllum intermedium Fomitchev, both of which are indigenous to layers $\mathrm{C}_{2}{ }^{5}-\mathrm{C}_{2}{ }^{6}$ of the Donets Basin, as well as Cystophora biseptata Dobrolubova, Multihecopora aff. penchiensis Yoh., and Neoconincophillum aff. tanacium Fom., all of which are indigenous to the upper levels of the Middle Carboniferous period. Moreover, Campophyllum cf. schrenkii Stuck. was detected, which is characteristic of the Late Carboniferous period in the Ural Mountains, together with Neoconincophyllum sp. nov., which is encountered in the $\mathrm{C}_{2}-\mathrm{C}_{3}$ deposits of the Russian platform (these determinations were made by B. V. Preobrazhenskiy).

Thus, aside from the Middle Carboniferous deposits that we detected, higher beds of Middle Carboniferous, Late Carboniferous, and possibly even Early Permian layers are probably present here (Michelinopora sp. nov. and Michelinopora sp., which are present in the Early Permian layers of southern China, were encountered). In this regard, the Late Paleozoic cross-section of Wrangel Island is unique to the eastern Chukot Peninsula structural-facial zone.

The coastal cliffs occupying the southeastern section of the island between the Polikarpych Creek estuary, Cape Waring, and Cape Utes Bol'shevik comprise the site that offers the most promise with respect to detailed 
biostratigraphic research.

\section{The Late Triassic Period}

Late Triassic deposits are predominantly distributed over the souther portion of Wrangel Island, where they make up the Mineyev, Somnitel'nyye [Dubious], Yevstifeyev, and Bezymyannyye [Nameless] Mountains of the Western and Eastern plateaus. Allochthon relics entrained by Triassic sandstones are noted in the Tsentral'nyye and Mamontovyye Mountains.

South of Cape Ptichiy Bazar, we saw Triassic clay shales and siltstone shales lying directly over Waring suite limestones of reef origin. A small area of mylonitized rocks with a thickness of $1.5-2.9 \mathrm{~cm}$ was noted at the stratal boundary. Similar Triassic and Carboniferous relationships were also detected between Cape Pillar and Cape Utes Bol'shevik, as well as at the headwaters of the Khishohnikov River.

This apparent "conformable" occurrence of Paleozoic and Triassic deposits can be explained by a highly complex folding, in one structural plan of which the Late Triassic and Early Carboniferous rocks are dislocated. S. M. Til'man, et al. (1963), observed distinct vestiges of underlying deposit roof washout at the headwaters of the Somnitel'naya [Dubious] River near Vysokaya Mountain. Here, the Paleozoic rock surface was "...sinuous, containing large pockets with a depth of as much as 10-20 m, interspersed with erosion-generated hollows, as well as large mounds". The magnitude of the angular variance existing between these Triassic and Early Carboniferous deposits comes to no less than $15-20^{\circ}$. The basal Triassic levels are made up of gritstones and oligomictic, sometimes coarse-grained sandstones.

Along Wrangel Island's southeastern shore, from Cape Utes Bol'shevik to Cape Gavai-1, we put together a layer-by-layer cross-section of Late Triassic deposits which was subsequently verified and duplicated in the 
Mineyev Mountains, as well as along the western shore of the island, from Cape Ptichiy Bazar to Cape Fomy. The actual cross-section of the Triassic deposits occupying the southern section of the island possesses the following structure:

1. Nonlayered black siltstones and clay shales containing discoidal clay-siderite concretions; imprints of Monotis pinensis West., M. scutiformis var. tipica Kipar., Halobia cf. celtica Mojs., H. sp. indet., and Otapiria cf. ussuriensis (Vor.) are present in

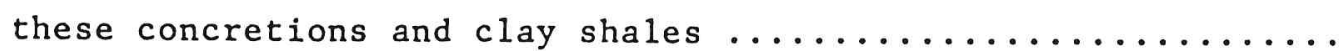

2. Greenish-grey oligomictic sandstones ............... 10-15 m

3. Siltstones containing ellipsoidal pyrite concretions, as well as Monotis jakutica (Tell.) and Halobia sp. indet. fauna ........

4. An interstratification of sandstones $(0.15-0.8 \mathrm{~m})$ and clay shales (0.05-0.08 m), with numerous imprints of Halobia sp. indet., Monotis jakutica (Te11.), and M. pinensis West........

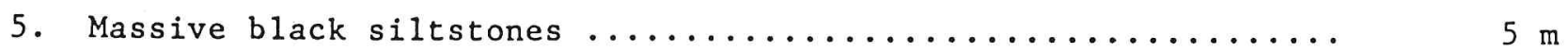

6. A smooth alternation of greenish and black siltstones ....... $14 \mathrm{~m}$

7. Fine-grained micaceous sandstones containing imprints of Monotis detritus and finely crushed phytodetritus $\ldots \ldots \ldots \ldots \ldots \ldots$.

8. An alternation of coarsely layered siltstones and finely layered small-grained sandstones; thin (up to $0.05 \mathrm{~m}$ thick) lenses of greenish and black limestones are encountered in these siltstones, together with Monotis scutiformis cf. var. daonellaefformis Kipar., M. scutiformis var. typica Kipar., M. ex gr.

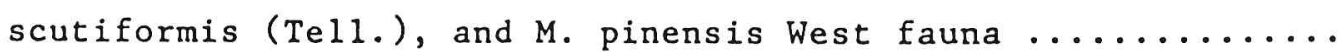

9. Dark grey obliquely layered siltstones $\ldots \ldots \ldots \ldots \ldots \ldots \ldots \ldots \ldots .6 . \ldots$

10. Grey smal1-grained layered sandstones ................ $2.0 \mathrm{~m}$ 
11. Strip-1ayered siltstones containing siderite concretions ....

12. Grey oligomictic and black micaceous sandstones ...........

13. A smooth interstratification of oligomictic sandstones and lay-

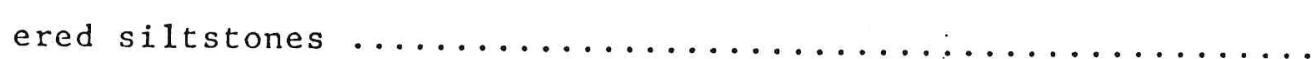

14. Sandstones containing infrequent siltstone intercalations, as well as Monotis scutiformis cf. var. daonellaeformis Kipar., M. ochotica (Keys.), M. ochotica var. ambiqua (Te11.), and M. ochotica cf. var. pachypleura (Te1l.) fauna ...............

15. Black micaceous sandstones containing plant detritus ........

16. Grey oligomictic sandstones containing sporadically distributed intercalations of siltstones and clay shales, with crushed Monotis shell fragments often being encountered ......

The overall thickness of the portion of this cross-section described above is $460-500 \mathrm{~m}$.

Thus, it is perfectly clear that Wrangel Island's entire Late Triassic rock stratum is lithologically divided into three members: a lower member, the composition of which is essentially of the shale type; a middle member, constituting a complex interstratification of sandstones and siltstones, and; an upper member, which is predominantly of the sandstone type.

A bed of sandy shale rocks containing lenses of slightly recombined reddish conglomerates and syngenetic clay-siderite concretions in which M. Ye. Gorodinskiy (1960) detected imprints of Monotis jakutica (Te11.), M. ochotica var. densistriata (Tell.), M. aff. subcircularis Gabb., and Cladiscites sp. indet. (these determinations were made by Yu. M. Bychkov and A. F. Yefimova) is situated above the sandstones occupying the coastal cliffs between the estuary of the Klark River and the Gavai elevations. 
- Erom Cape Ptichiy Bazar to Cape Fomy - duplicates and confirms the stratigraphic layout of Late Triassic deposits previously presented. It is true that a larger number of limestone lenses is observed in the region of Cape Gil'der as far as we know and that the thickness of the lower shale member is increased, reaching a magnitude of $350-400 \mathrm{~m}$ in this location.

The Late Triassic rocks of Wrangel Island achieve an overall thickness of $500-800 \mathrm{~m}$.

Aside from the Mesozoic rock outcrops previously mentioned, the formations making up the Bezymyannyye [Nameless] Mountains, Tundrovyy [Tundra] Peak, and a number of outcrops of the sandy shale stratum forming a boundary with the Akademiya [Academy] Tundra are tentatively relegated to the Late Triassic period on the basis of a lithological similarity to the cross-section that is already documented faunistically. For this same reason, certain erosion-generated and tectonic outliers occupying the central section of the island, situateded both on Carboniferious rocks and on the Precambrian metamorphites of the Tsentral'nyye Mountains, are also relegated to the Late Triassic period.

Based on faunistic determinations, these Late Triasic deposits are dated to the late portion of the Carnian stage and the substructure of the Norian stage. The uppermost Carnian beds are characterized by Halobia cf. celtica Mojs., Halobia cf. aotti Kob. et Ichik., H. ex gr. superba Mojs., Monotis pinensis West., M. setakanensis Kipar., M. scutiformis cf. var. daonellaeformis Kipar., and M. scutiformis var. typica Kipar. Monotis jakutica (Te11.), M. ochotica var. ambigua Tel1., M. ochotica cf. var. pachypleura (Te11.), M. scutiformis cf. var. daonellaeformis Kipar., and Cladiscites sp. are present in the Early Norian deposits (these determinations were made by L. V. Milova).

Since the material compositions of the Late Carnian and Early Norian 


\begin{abstract}
layers occupying the stage boundary scarcely differ at all, the boundary between these stages can only be traced by means of faunistic assemblages. However, generally speaking, but quite clearly, the boundary between the Carnian and the Norian stages can not be discerned all the same. In the general case, the shale member and the interstratified shale, siltstone, and sandstone beds located in the upper portion thereof are relegated to the upper levels of the Carnian stage, while the member composed primarily of sandstone falls into the Early Norian stage.
\end{abstract}

\title{
References
}

1. Gnibidenko G. S. Novyye dannyye po stratigrafii paleozoya ostrova Vrangelya. Dokl. AN SSSR, t. 179, 2, 1968.

1. G. S. Gnibidenko. New data on the stratigraphy of Wrangel Island's Paleozoic formations. Reports From the Soviet Academy of Sciences, Vol. 179, No. 2, 1968.

2. Ivanov 0 . N. $K$ voprosu o vozraste metamorficheskikh porod o-va Vrangelya. Uch. zap. NIIGA, vyp. 15, 1969.

2. 0. N. Ivanov. The question of the age of Wrangel Island's metamorphic rocks. Scientific Notes From the Scientific Research Institute of Arctic
Geology, No. 15, 1969.

3. Lobanov M. F. Geologicheskoye stroyeniye o-vov Vrangelya i Geral'da. Tr. NIIGA, t. 81, 1957.

3. M. F. Lobanov. Geological structure of Wrangel and Herald islands. Works of the Scientific Research Institute of Arctic Geology, Vo1. 81, 1957.

4. Til'man S. M., Byalobzheskiy S. G., Chekhov A. D., Kuvayev O. M. Geo1ogicheskoye stroyeniye o. Vrangelya. Tr. SVKNII SO AN SSSR, vyp. 11. Magadan, 1964.

4. S. M. Til'man, S. G. Byalobzheskiy, A. D. Chekhov, O. M. Kuvayev. Geological structure of Wrangel Island. Works of the Northeastern Multidisciplinary Scientific Research Institute, Siberian Branch, Soviet Academy of Sciences, Magadan, No. 11, 1964.

Northeastern Multidisciplinary Scientific Research Institute, Far East Science Center, Magadan
Article submitted to the editorial office January 23, 1972 


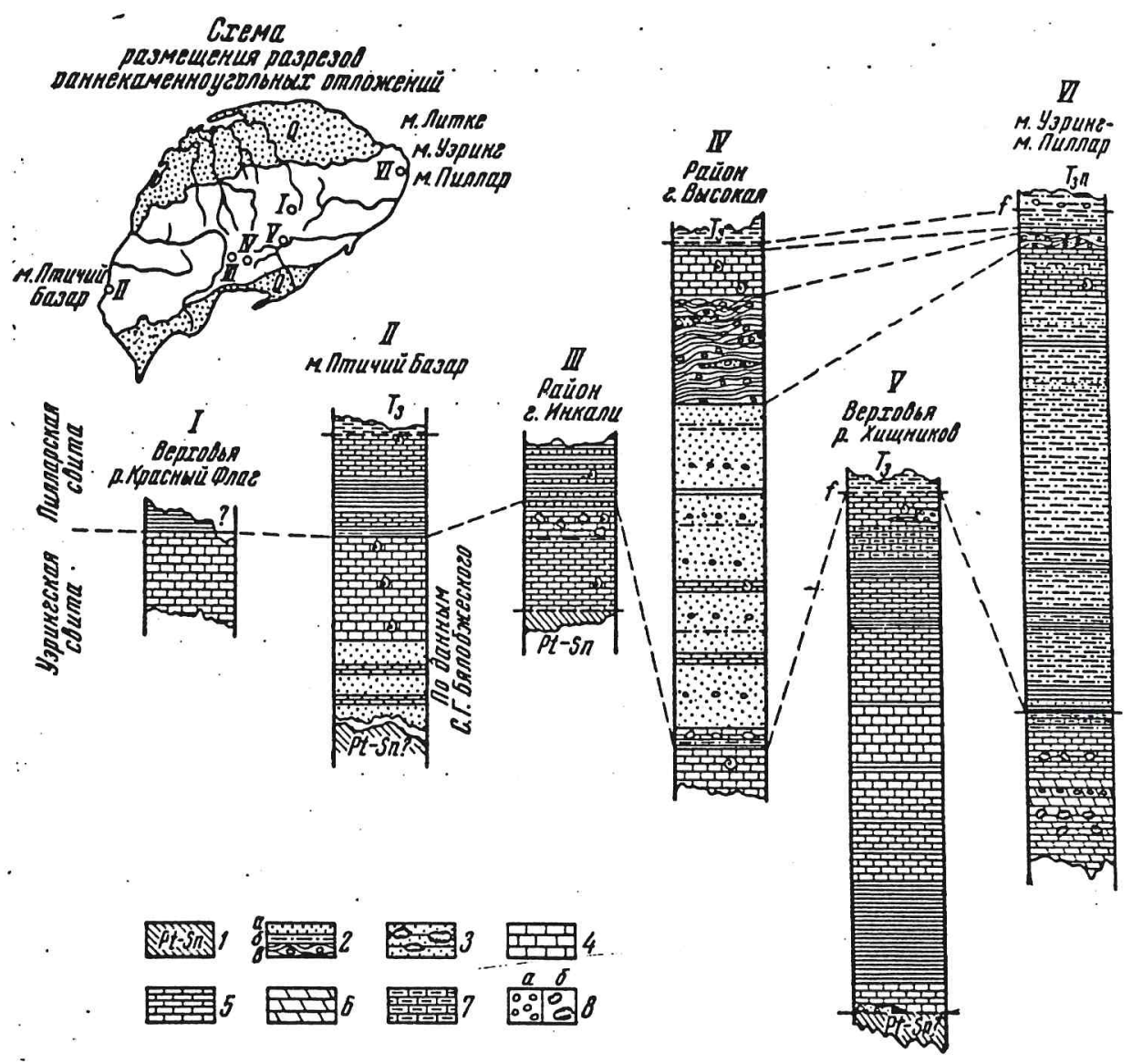

Схема корреляции раннекаменноугольных разрезов о. Врангеля

1 - врангелевский метаморфический комплекс; 2- песчаники (a), алевролиты (6),

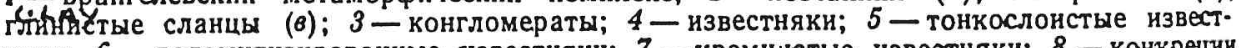
яяки; 6 -доломитизированные ґизвестняки; 7 - кремнистые известняки; 8-конкреции (a) и включения (б)

зований палеозоя: 1) исходный состав пород отвечает вулканогенно-осадочному комплексу с явным преобладанием грубообломочных кварцевых пород, 2) породы комплекса метаморфизованы в фации зеленых сланцев, 3) метаморфическая толща насыщена интрузивными телами амфиболитов, габбро, граносиенитов и натровых гранитов, отсутствующих в вышележащей палеозойской толще. Отметим также, что на Чукотке среди достоверных палеозойских отложений от ордовика до намюра нет аналогов описанным выше метаморфитам.

В то же время сопоставление врангелевского комплекса с протерозой. ско-синийскими образованиями Северо-Востока обнаруживает их существенное сходство. С метаморфической толщей о. Врангеля хорошо сопоставляются разрезы Авековского поднятия (кварциты, филлиты, мраморизованные известняки с Collenia), бухты Аян (слюдяные кварцитовые сланцы, кварцитовидные песчаники, песчаники и филлиты), бурустасской свиты о. Большого Ляховского (рассланцованные песчаники и филлитовидные серицито-хлоритово-кварцевые сланцы) и становской свиты п-ова Челюскин (конгломераты с галькой кварца и изверженных пород, кварциты, кварцитовидные песчаники, филлиты, хлоритовые сланцы).

Сходная геологическая позиция и литологическое подобие врангелевского метаморфического. комплекса и достоверных протерозойскосинийских разрезов на прщтегающнх территориях, по-видимому, свиде- 
Калин̆-аргоновый возраст „.. Аних метаморфических и нзверженных пород с рангеля

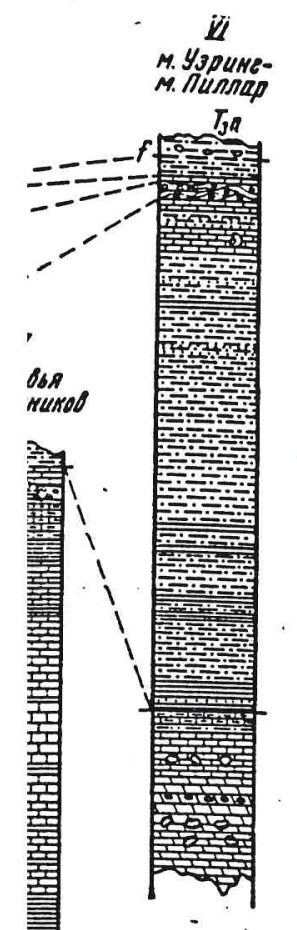

毫

нгеля

алевролиты (б) слоистые извест ки; 8 - конкрецни

каногенно-оса ыых кварцевых зеленых слантелами амфнगтсутствующих го на Чукотке Iо намюра нет

( с протерозойвает их суще ля хорошо сориллиты, мрае кварцитовые (ы), бурустасчаники и филновской свиты кенных пород. Iе сланцы). добне врангеıротерозойскоимому, свиде-

\begin{tabular}{|c|c|c|c|c|c|c|c|}
\hline \multirow{2}{*}{ 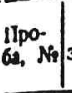 } & \multirow{2}{*}{ 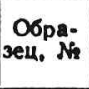 } & \multirow{2}{*}{ Порода и место амятия пробы } & \multicolumn{3}{|c|}{ Содержанне, г/а } & \multirow{2}{*}{$\frac{\mathrm{Ar}^{40}}{\mathrm{~K}^{20}}$} & \multirow{2}{*}{$\begin{array}{l}\text { Bospacr, } \\
\text { млн. лечет }\end{array}$} \\
\hline & & & $\mathbf{K}$ & $K^{4 p}$ & Arto & & \\
\hline 4269 & 159 & $\begin{array}{l}\text { Лейкократовый граннт, гора } \\
\text { Осьмнног }\end{array}$ & 0,0208 & 2,53 & 5 & 0,0205 & 321 \\
\hline 4270 & 79 & $\begin{array}{l}\text { Лейкократовый гранит, гора Ин: } \\
\text { кали }\end{array}$ & 0,0108 & 1,32 & $\begin{array}{l}2,21 \\
2,22\end{array}$ & $\begin{array}{l}0,0207 \\
0,0167\end{array}$ & 265 \\
\hline 4271 & 164 & $\begin{array}{l}\text { Қварц-полевошпатовый сланец, } \\
\text { верховье р. Хинников }\end{array}$ & 0,0175 & 2,14 & 3,71 & 0,0173 & 275 \\
\hline 4273 & 98 & $\begin{array}{l}\text { Галька гранодиорит-порфира, } \\
\text { Мамонтовые горы }\end{array}$ & 0,0325 & 3,97 & 0,0119 & 0,0110 & 194 \\
\hline $\begin{array}{l}4274 \\
4275\end{array}$ & $\begin{array}{l}151 \\
966\end{array}$ & $\begin{array}{l}\text { ье р. Хищников } \\
\text { полевошпатовый } \\
\text { дтовые горы }\end{array}$ & $\begin{array}{l}0,0406 \\
0,0138\end{array}$ & $\begin{array}{l}4,96 \\
1,27\end{array}$ & $\begin{array}{l}5,75 \\
4,39\end{array}$ & $\begin{array}{l}0,0116 \\
0,0345\end{array}$ & $\begin{array}{l}187 \\
513\end{array}$ \\
\hline 4276 & $163 r$ & $\begin{array}{l}\text { вернистых грани- } \\
\text { р. Хищников }\end{array}$ & 0,0102 & 1,245 & $\begin{array}{l}4,89 \\
4,90\end{array}$ & & $\begin{array}{l}574 \\
575\end{array}$ \\
\hline 4277 & $163 \mathrm{~B}$ & Амфиболит, верховье р. Хищни- & 0,0054 & 0,658 & 0,464 & 05 & 115 \\
\hline 4278 & $\begin{array}{r}166 \\
97\end{array}$ & $\begin{array}{l}\text { Очковый гнейс, гора Громова } \\
\text { Очковый гнейс, Мамонтовые го- } \\
\text { ры }\end{array}$ & $\begin{array}{l}0,0404 \\
0,0357\end{array}$ & $\begin{array}{l}4,94 \\
4,36\end{array}$ & $\begin{array}{l}5,45 \\
6,04\end{array}$ & & $\begin{array}{l}179 \\
230\end{array}$ \\
\hline 1218 & $231-3$ & $\begin{array}{l}\text { Флюидальный порфир, гора Пер- } \\
\text { вая }\end{array}$ & 0,0335 & 4,33 & 3,49 & $0,008 \mathrm{C} 7$ & 133 \\
\hline 1895 & $54 a$ & $\begin{array}{l}\text { Среролитовый квэрц-полевошпа- } \\
\text { товый порфир, руч. Хрусталь- } \\
\text { ный }\end{array}$ & 0,0473 & 5,76 & 4,20 & 0,00729 & 121 \\
\hline 1855 & $421 \cdot \mathrm{e}$ & $\begin{array}{l}\text { Слюдисто-полевошпатовый сла- } \\
\text { нец, истоки р. Хищников }\end{array}$ & 0,0342 & 4,17 & 4,35 & 04 & 170 \\
\hline 1856 & 4236 & овый гранит, верховья & 0,0367 & $\sim 4,48$ & 4,53 & 0,0101 & $165 \pm 3$ \\
\hline 1857 & $406 a$ & $\begin{array}{l}\text { товый грзнит-порфир, } \\
\text { е р. Хищников }\end{array}$ & 0,0426 & 5,20 & 5,68 & 0,0109 & $178 \pm 5$ \\
\hline 1219 & $255 a$ & $\begin{array}{l}\text { Лейкократовый гранит, район вы- } \\
\text { соты } 605.0 \text { м }\end{array}$ & 0,0349 & 4,26 & 5,63 & 0,0132 & ? \\
\hline 1858 & $55 a$ & ${ }_{\text {нранит-порфир, руч. Хрусталь- }}$ & 0,0432 & 5,26 & 6,93 & 315 & $212 \pm 6$ \\
\hline 1851 & 4146 & $\begin{array}{l}\text { Хлорит-серицитовый сланец, вер- } \\
\text { ховье р. Хищников }\end{array}$ & 0,0097 & 1,18 & 2,05 & 174 & $276 \pm 3$ \\
\hline 1852 & $426 a$ & $\begin{array}{l}\text { Измененный диабаз, верховье } \\
\text { р. Неизвестной }\end{array}$ & 0,0096 & 1,17 & 1,915 & 0,0164 & $262 \pm 8$ \\
\hline 1861 & 75 & $\begin{array}{l}\text { Қварцитовый сланец, район } \\
\text { м. Флэренс }\end{array}$ & $0,0042^{5}$ & 0,52 & 0,865 & 0,0166 & $264 \pm 45$ \\
\hline 1220 & $267 a$ & $\begin{array}{l}\text { Гранодиорнт-порфир, гора Со- } \\
\text { ветская }\end{array}$ & & $\begin{array}{l}0,52 \\
3,95\end{array}$ & 7,08 & & \\
\hline 1853 & 225 & $\begin{array}{l}\text { Мусковитовый гранит, гора Ось- } \\
\text { миног }\end{array}$ & & 3,16 & 8,73 & & $421 \pm 6$ \\
\hline 1854 & 4216 & $\begin{array}{l}\text { Мусковиты п плагиогранит, исто- } \\
\text { к! р. Хнщников }\end{array}$ & & $\begin{array}{l}1,48 \\
1,48\end{array}$ & & & \\
\hline 186.? & 412 & $\begin{array}{l}\text { Галька порфнров из конглэмерз- } \\
\text { та р. Хищников }\end{array}$ & & 120 & 3 & & \\
\hline $\begin{array}{l}1221 \\
186 \cdot 2\end{array}$ & $\begin{array}{l}512 \\
215\end{array}$ & $\begin{array}{l}\text { Амфнболит, гора Сэветская } \\
\text { Аркозэвый песчан!เк, гора Со- }\end{array}$ & 0,0124 & 1,51 & 4,56 & & $457 \pm 25$ \\
\hline 1863 & $4 C 4 a$ & $\begin{array}{l}\text { ветская } \\
\text { Рассланцованный песчаник, Цент- } \\
\text { ральныте горы }\end{array}$ & & $\begin{array}{l}2,28 \\
1,57 \\
1,57\end{array}$ & $\begin{array}{l}3,79 \\
2,75 \\
2,95\end{array}$ & & $\begin{array}{l}264 \pm 3 \\
278 \pm 5 \\
296 \pm 5\end{array}$ \\
\hline 18 & 536 & $\begin{array}{l}\text { Аркозовый песчаник, ручей Хру- } \\
\text { сталььный }\end{array}$ & 0,0 & 2,28 & 2 & 5 & $273 \pm 7$ \\
\hline 18 & 41 & $\begin{array}{l}\text { Аркозовый песчаннк, Централь- } \\
\text { ные горы }\end{array}$ & $\begin{array}{l}0,0257 \\
0,0257\end{array}$ & $\begin{array}{l}3,14 \\
3,14\end{array}$ & $\mid \begin{array}{l}3,32 \\
3,36\end{array}$ & & $\begin{array}{l}173 \pm 8 \\
175 \pm 8\end{array}$ \\
\hline
\end{tabular}

П р и ме ч а н н е. Аналнз про6 4269-4279 пронзведен Н. П. Загрузиной (1968) по образцам нз колМ. Е. Городннского (1962) и $1851-1865-\mathrm{C}$. Л. В. Фирсозым (1966) по коллекциям: о6р. 1218-1221Константы определеншя: $\lambda_{\beta}=4,68 \cdot 10^{-10}, \lambda_{K}=0,585 \cdot 10^{-10}$. .. Г. Бялобжеского 